\title{
Female Hands: Embroidery as a Knowledge Field in Women's Everyday Life in Late Imperial and Early Republican China
}

\author{
Grace S. Fong
}

Hands

Having just put aside the silver plectrum, She sits down and picks up the gilded needle.

To make drawing lots she writes in small standard script, Competing at gathering flowers she breaks her delicate nails.

They are easy to turn over but it's hard to know what they express. They can reach out so one doesn't object to their softness.

Holding a golden shuttle, she weaves by the loom, Close-fitting sleeves conceal slenderness. ${ }^{1}$

Huang Yunxiang (Qing Dynasty)

This paper was first presented at the International Symposium on "Daily Life, Knowledge, and Chinese Modernities,” held at the Institute of Modern History, Academia Sinica, November 2123, 2002. I am most grateful to Hsiung Ping-chen for organizing our panel. I also wish to thank Peter Zarrow for his thoughtful comments. I am, however, most indebted to the anonymous readers for Late Imperial China for their incisive critiques and suggestions. I have endeavored to address the issues they raised while maintaining the integrity of my approach. As always, my immense appreciation goes to Robin Yates for reading my drafts and refining my translation of the poetry.

${ }^{1}$ Yun Zhu and Wanyan Miaolianbao, eds., Guochao guixiu zhengshi xuji (8.4a). For further details, see n. 5 . 
We seek those ruled by partial sight and limited voices-not partiality for its own sake but, rather, for the sake of the connections and unexpected openings situated knowledges make possible. $^{2}$

\section{Donna Haraway}

\section{Introduction}

In late imperial China, female hands performed various tasks that had to be learned, from mundane, gender-specific work such as binding the feet, holding an infant, weaving, sewing, embroidering, preparing food, to more exalted forms of cultural performance such as playing a musical instrument, holding a book to read, or moving a brush over the surface of paper to write or paint. Many of these activities required or implied extensive training and discipline; some entailed rigorous and regular practice from a young age. The skilful female hand, then, in a metaphoric as well as literal sense, gave rise to the productivity and visibility of many Chinese women recovered by contemporary historians and scholars of literature.

In this study I explore specifically how the female hand is connected to knowledge and the construction of subjectivity and homosociality in the everyday practice of embroidery. I take as my guiding premise that women were the subordinate group within the orthodox Chinese gender and social hierarchy, but, in spite of, or because of, their subordination, I want to draw on the notion of everyday practice through which the French scholar Michel de Certeau sought to

\footnotetext{
${ }^{2}$ Donna Haraway, “Situated Knowledges: The Science Question in Feminism and the Privilege of Partial Perspective,” Feminist Studies 14.3 (1988): 590.
} 
re-vision and empower consumers, the "dominated element in society," as inventive in the ways they "make (bricolent) innumerable and infinitesimal transformations of and within the dominant cultural economy in order to adapt it to their own interests and their own rules.”3 Although my emphasis on women as producers seems to run counter to Certeau's focus on consumers, I see their inferior status in a dominant culture as broadly analogous. Certeau resuscitates the "passive," "colonized” consumers of popular culture by identifying their tactics and inventiveness in acts of everyday life such as reading, walking, and cooking. ${ }^{4}$ Chinese women were constructed by Confucian gender ideology as "passive readers” or "recipients,” figuratively speaking, of the dominant culture. This statement is not meant to revive the stereotype of the victimized traditional woman that has been deconstructed by the seminal work of social historians such as Dorothy Ko and Francesca Bray. However, I am mindful that, despite women's active participation in and contribution to family and, by extension, social and economic life, their sphere of action and influence remained circumscribed by the hegemony of orthodox Confucian ideology. Therefore, to approach women's subjectivity from the critical perspective of the everyday could disclose modes of experience and agency otherwise obscured, and demonstrate, in concrete instances, the complex and partial ways in which women negotiated positions of empowerment, knowledge, and authority. I believe the focus on the subject of embroidery, as practiced and represented by literate women of the gentry class, constitutes a productive way in which to explore the relation between forms of local practice and knowledge and possibilities for social transformation, as I elaborate below. From a political and social

${ }^{3}$ Michel de Certeau, The Practice of Everyday Life (Berkeley: University of California Press, 1984), xi-xiv.

${ }^{4}$ See Certeau, The Practice of Everyday Life, "General Introduction.” 
concern inspired by feminist theorizing on agency and subjectivity and by feminist activism for women who continue to be subordinated in societies and cultures of the present, I hope in my study to recover certain modes of agency, if not resistance, among Chinese women of the past that can broaden and deepen our contemporary horizons of understanding.

In the Ming and Qing, as female literacy became more widespread among the educated classes, many women persevered as producers of varied forms of knowledge in the context of their daily lives, even when few normative, regular channels existed for their expertise to be recognized and disseminated within the social system. Within this historical and ideological framework, I want to examine certain effects of the practice of embroidery—with its intimate identification as a "boudoir" art and skill—as a form of knowledge that derived from women’s everyday life. I argue that, through embroidery as practice and knowledge, individual women were able to create a space of local and limited empowerment for themselves and other women. The nuances in their sense of empowerment can be discerned in significant ways through texts they themselves produced on the subject of embroidery: poetic writings, treatises, and manuals. If not for the fact that women wrote explicitly about this activity and, furthermore, linked it with writing and literary composition, the personal, local sense of knowledge and power and the alternative social space associated with it would be that much more invisible.

Embroidery is a rich topic that can be fruitfully approached from a number of disciplinary perspectives: material culture, art history, social and economic history, science and technology, to name but a few. Indeed, ideally it should be approached from an interdisciplinary perspective involving a team of specialists. In the present study, I aim to make my contribution to the subject as a literary scholar informed by gender and cultural studies. I approach, then, how the multivalent "female hand" is manifested in the instance of embroidery through critical readings 
of women's literary productions on the subject. In my analysis, I attempt to contextualize these texts in women's emotional, social, and to some extent, economic life.

In the first part of the study, I begin by examining women's literal and metaphoric inscription of embroidery in their poetry as representations of their everyday experience and fields of knowledge. I discuss the common topos and citation of embroidery in women's poetry and their collections named after embroidery to establish how these tropes function and how they signify emotion, knowledge, and experience. Published in the 1830s, Guochao guixiu zhengshi ji (Anthology of Correct Beginnings by Talented Women of the Present Dynasty), the vast anthology of several thousand poems by women of the Qing compiled by Yun Zhu (1771-1833), provides many examples of the embroidery topos. ${ }^{5}$ On the one hand, its more substantial inclusion of poems with the embroidery topos than anthologies of women's poetry compiled in the late Ming and early Qing, such as Mingyuan shigui (printed ca. 1626) by Zhong Xing (15741624) and Mingyuan shiwei (printed 1667) by Wang Duanshu (1621-ca. 1706), can be seen as an indication of how women increasingly associated the two practices of embroidery and poetry writing in their everyday life, an association that can be seen concretely in the examples analyzed

${ }^{5}$ Guochao guixiu zhengshi ji (hereafter Zhengshi ji) was printed in 1831; the sequel Guochao guixiu zhengshi xuji (hereafter Zhengshi xuji) was completed by Yun Zhu’s granddaughter Wanyan Miaolianbao and printed in 1836. On the Zhengshi ji as Yun Zhu’s anthologizing project and discussions of selected poems, see Susan Mann, Precious Records: Women in China's Long Eighteenth Century (Stanford: Stanford University Press, 1997), 94-116. We do not have even rough dates for most of the women included in this anthology. The overall period of coverage is from the Ming-Qing transition in the seventeenth century to Yun Zhu's own day. 
below. ${ }^{6}$ On the other hand, these poems can also be seen as a reflection of Yun Zhu's editorial principles in selection, which highlight both talent and virtue in women's poetry. ${ }^{7}$ Poetry is the expression of women's literary talent, and poems by women on doing embroidery, that is, performing woman's work (nügong), could be perceived as positive representations of virtuous conduct.

I have drawn on another accessible corpus of women's poetic texts, the collection Suiyuan nüdizi shixuan (Selections of Poems by the Female Disciples of Suiyuan). ${ }^{8}$ In addition to providing us with the poetry of a nicely demarcated social and literary group—nineteen gentlewomen who identified themselves as disciples of the famous poet Yuan Mei (1716-1798), champion of women's poetry, and who thus lived in the same time period (late eighteenth century) and geographical region (the Yangzi Delta or Jiangnan region), this corpus is also valuable for the self-selection that went into its making. Yuan Mei decided to publish not only the poems that these women had sent him in direct correspondence with or in reply to him, but also other poems that they had sent him as examples of their poetic oeuvres, that to them

${ }^{6}$ On these and other Ming and Qing anthologies of women's poetry, see Kang-i Sun Chang, “Ming and Qing Anthologies of Women’s Poetry and their Selection Strategies," in Ellen Widmer and Kang-i Sun Chang, eds., Writing Women in Late Imperial China (Stanford: Stanford University Press, 1997), 147-170.

${ }^{7}$ See Susan Mann's translation of Yun Zhu's preface to the anthology and her discussion of the issues of women's scholarly and moral authority in relation to their poetic writing in the context of the debates in the High Qing, Precious Records, 94-98.

${ }^{8}$ In Yuan Mei, Yuan Mei quanji (Nanjing: Jiangsu guji chubanshe, 1993), vol. 7, 1-147 (separate pagination). 
expressed their sense of themselves as writing subjects. In other words, these women themselves selected poems that would be read in a social and more "public" space. Relevant to this study are the inclusion of poems that refer to embroidery in ways that both complement and supplement the examples from Yun Zhu's anthology. Finally, I also include in my discussion the poetry collection Yongxuelou shicun (Poetry from the Pavilion of Singing About Snow) of Gan Lirou (1743-1817), and the poems related to embroidery in it. They succinctly illustrate the points I make through the life and poetic writings of a single author.

In the second part of the study, I engage with a different genre of writing: that of the manual or illustrated treatise on a subject ( $p u$ or $t u$ ), and in the present context, those produced by women. This genre is an important site for demonstrating a person's knowledge and authority in a particular field. Specifically, I examine three manuals on the subject of embroidery: the Cixiu tu (Illustrations of Embroidery) by Zhang Shuying (dates unknown) of the Ming period or earlier, Хіuрu (Treatise on Embroidery, preface dated 1821) by Ding Pei (fl. first half of 19th century), and Xuehuan xiupu (Treatise on Embroidery by Xuehuan), narrated by Shen Shou (1872-1921) and recorded by Zhang Jian (1853-1926). ${ }^{9}$ To my knowledge, while men wrote extensive works and treatises on technology and agriculture, including that of weaving and

${ }^{9}$ The editions used are: Zhang Shuying, Cixiu tu, in “Guige bu: nügong,” in Qinhuai Yuke, ed., Lüchuang nüshi, juan 1; Ding Pei, Xiupu, in Congshu jicheng xubian (Shanghai: Shanghai shudian, 1994), vol. 79, 795-804; Shen Shou, Xuehuan xiupu, in Congshu jicheng xubian (Shanghai: Shanghai shudian, 1994), vol. 79, 805-819. Ding Pei’s Xiupu is also included in Zhonghua Meishu congshu (reprint of Meishu congshu, 1947; Beijing: Beijing guji chubanshe, 1998), and in the collectanea Xiyongxuan congshu, compiled and published by Tao Xiang in Beijing, 1929. 
sericulture, they did not produce any manuals or special books on the subject of embroidery, a practice that was so intimately associated with women's lives in the inner quarters. Dating from the late imperial through the early Republican period, the three texts on embroidery by women not only tell us about women's attitudes towards a skill and field of knowledge traditionally associated with the domain of women, they also indicate important historical moments of women's self-perception and position in knowledge production in China.

\section{Textualizing Embroidery: Everyday Practice and Women's Poetry}

\section{Women's Work: Weaving}

Several seminal studies of the social and cultural history of women and gender in late imperial China have each devoted attention to the feminine skill of embroidery as part of woman's work in pre-twentieth century China. ${ }^{10}$ In my analysis, I draw on their important observations to contextualize women's texts on embroidery. As set forth in the Li ji (Record of Rites) and reiterated by Ban Zhao (c. 48-c. 120) in her subsequently influential didactic text the Nü jie (Precepts for Women), woman's work (nügong) was the fourth canonical womanly virtue following morality, speech, and conduct. ${ }^{11}$ An important aspect of woman's work, embroidery

${ }^{10}$ See the sustained discussion of women’s work by Francesca Bray, in Technology and Gender: Fabrics of Power in Late Imperial China (Berkeley: University of California Press, 1997), chapters 4-6, and 265-269 that focus on embroidery. See also Dorothy Ko, Teachers of the Inner Chambers: Women and Culture in Seventeenth-Century China (Stanford: Stanford University Press, 1994), 172-175; and Susan Mann, Precious Records, passim.

${ }^{11}$ See Nancy Lee Swann, Pan Chao: Foremost Woman Scholar of China (Rpt., Ann Arbor:

Center for Chinese Studies, University of Michigan, 2001), 86; and James Legge, tr., Li ki, in 
has been practiced by women in China from earliest times since the development of sericulture. However, it was not as basic a skill as weaving, which played an important social and economic role in the classical gendered division of labor, phrased as "men plough and women weave" (nangeng nüzhi). ${ }^{12}$ As Francesca Bray has shown, until the Single Whip tax reforms (1581) of the late Ming when cash replaced textile and grain as household tax payments to the government, even women in upper-class households would engage in the production or management of the production of cloth, namely, spinning and weaving (figure 1$).{ }^{13}$

As a subject in women's poetry, weaving could play its role naturally in the ideal of the gendered division of labor. This representation of weaving might take the form of didactic instruction. For example, the poem entitled "Women’s Precepts” written by a matriarch to teach married women (most immediately, those in her own household) on how to conduct themselves in their various responsibilities in life includes weaving in a couplet regarding the proper training of children along gendered lines:

As for daughters, we instruct them in spinning,

As for sons, we instruct them in the Classic of Poetry and the Documents. ${ }^{14}$

Sacred Books of the East, ed. Max Müller (Oxford: Clarendon Press, 1879-85), vol. XXVIII, 432.

${ }^{12}$ Bret Hinsch discusses in detail the gendered moral and cultural significations of "cloth making” (weaving) conveyed in Pre-Qin and Han texts. See "Textiles and Female Virtue in Early Imperial Chinese Writing,” NAN NÜ: Men, Women and Gender in China 5.2 (2002).

${ }^{13}$ See Francesca Bray’s discussion in Technology and Gender, 187, 199-203.

${ }^{14}$ Li shi, “Women’s Precepts,” Zhengshi ji 1.10a. 
While the ideal, most basic training and occupation of women in this scholarly family remains weaving, significantly the class context transforms male labor from "ploughing” into classical learning, scholarly pursuits that would prepare boys for the civil service examinations, which in turn would lead them ideally to a successful career in the government bureaucracy.

As might be expected, weaving was often represented as productive work by women, an activity with economic significance. Using the trope of spinning and weaving, women wrote poems of social criticism in which the female persona is a weaver in a poor family who labors through the night to make a living: ${ }^{15}$

On her loom she will surely weave a hundred feet of silk How unjust that she toils with needle and thread for others. ${ }^{16}$

Significantly, poems in which the motif of weaving appears, such as the above, often draw attention to its economic function. It is work that women, especially widows, could engage in at home to provide subsistence income for their families, usually to support their parents-in-law and children, sometimes also their own parent(s). In Yun Zhu's anthology of women's poetry, a woman's role as provider for the family through her labor as weaver appears more frequently in the biographical information than in the poems themselves. For example, a woman known as Zhang Yigu "Righteous Aunt Zhang” (seventeenth century) remained unmarried in order to bring up her orphaned nephew. She is said to have "spun day and night" so as to keep herself and her nephew alive (Zhengshi ji 3.1b). Kong Jiying, whose husband left her to journey afar, "taught

${ }^{15}$ When the female persona is not identified with the writer herself, that is, when the poem is not self-referential or autobiographical, it tends to be poetry of social criticism in the yuefu subgenre, as indicated by the poem title.

${ }^{16}$ Fu Mengqin, "Sigh of the Spinner,” Zhengshi ji 7.6b. 
her son to read and write while spinning and weaving through the night with her maid (Zhengshi ji 8.10a).” The young widow Wang Feiqiong was so poor that she sold her only silver bracelet for startup capital so she could weave to support her in-laws and raise her orphans (Zhengshi ji 8.22a). The biographical note on Zhou Shulü, also a young widow with three orphans, tells how she had to hire herself out to sew for subsistence. Zhou Shulü also recorded her hardships in her own voice in a series of eight strongly self-expressive poems entitled "Narrating My Thoughts." She devoted the fourth poem in the series to describe the travail of weaving. Through the medium of the poetic text she demonstrates her perseverance in fulfilling her duty as a widow:

Creaking - the sound of shuttle and loom,

Boundless - the snow in the empty sky.

I work until it's past midnight,

The skin on my fingers is all broken and chapped.

It isn't easy to gather together strands of silk,

But I can’t bear to stop in the middle.

Wearing this plain mourning garment,

I would gladly go to the same grave. ${ }^{17}$

The poem details briskly the harsh conditions in which she toils. The writer records with the same calloused hands how she doggedly spins past midnight with snow falling outside. There is a parallel between the severity of nature and her straitened circumstances. In the third couplet the image of reeling threads veers towards a figuration of continuity versus breaking off, particularly when read against the other poems in the series about her orphaned children—stopping the loom would mean ending her children's means of survival and thus bringing about their deaths. The

${ }^{17}$ Zhengshi ji 6.6b. 
last couplet also suggests that Zhou Shulü has forfeited suicide, which was regarded by some as an easy way out of a lifetime of widowhood. ${ }^{18}$ The poem implies that every day that she chooses to remain alive, she lives and works for the sake of her orphaned children, whom she is raising on behalf of her late husband. In these examples of poetry and biography, the figuration of weaving clearly denotes the strong moral character of the women.

\section{Women's Work: Embroidery}

While weaving often appears both in biographical representation and also in women's self-representation as the trope for a virtuous, honorable means of livelihood through which a woman could support herself and her close kin, embroidery acquired the status of a refined occupation for women in economically and socially more well-to-do households, and it is often represented as such in poetry by these women. Not that embroidery did not provide a means of livelihood for some women: in addition to the majority of women from the lower classes who toiled in obscurity, some, such as Li Qinghui and Sun Xuying, are examples of literate women who were noted to have used their embroidering skill as an economic resource (Zhengshi ji 20.16b, Zhengshi xuji 3.2a). However, embroidering appears less frequently than weaving in that pragmatic function in textual records. As a de rigueur art and skill that young girls from elite families would learn from their mothers and other older female kin at an early age and supposedly continue to practice through most of their lives, passing their skill and knowledge in turn to the next generation, embroidery became very much a part of women's daily experience that was manipulated as a topos in their poetic self-representation. The range of objects to be embroidered just in preparation for a young women’s trousseau might include shoes, leggings,

\footnotetext{
${ }^{18}$ For a study of female suicide, see Paul S. Ropp et al., eds., Passionate Women: Female
} Suicide in Late Imperial China (Leiden: Brill, 2001). 
purses, sashes, handkerchiefs, bedding, clothes and other materials made of fabric. The preparation of the dowry would involve young girls themselves producing these embroidered items under the guidance and with the help of their mothers, older sisters, and sometimes other female kin (figure 2). The embroidered products would show her husband's family her dedication, skill, and artistic taste. In discussing the often complementary experience of embroidery and painting in the lives of Ming and Qing women, art historian Marsha Weidner has observed succinctly that "[t]hrough embroidery women trained their hands and eyes, became attentive to the smallest details, refined their color sense, and mastered a large repertoire of motifs and compositional formulas." ${ }^{19}$ Although the high demand for embroidery in the context of Chinese social, ritual, aesthetic, and official life made it into a commodified skill that had to be supplied or supplemented by the labors of women from the lower classes, it remained a consistent part of elite young girls” program of “study.” Again, in Weidner’s words, “Needlework was the premier feminine art, one measure of a woman's worth." ${ }^{20}$ In an autobiographical poem, embroidering marks a stage in a young girl's cultivation, one that is closely linked to poetic craft: “At thirteen I learned how to embroider/At fifteen I learned how to chant poetry."21

In commenting on women's work, Susan Mann summed up the pertinent functions of embroidery for women in the High Qing: “Embroidery—considered work—might serve as well

${ }^{19}$ Marsha Weidner, "Women in the History of Chinese Painting," in Views from Jade Terrace: Chinese Women Artists 1300-1912, ed. Marsha Weidner et al. (Indianapolis and New York: Indianapolis Museum of Art and Rizzoli, 1988), 21.

${ }^{20}$ Marsha Weidner, “Women in the History of Chinese Painting," 21.

${ }^{21}$ Hang Wenru, “Self Lament,” Zhengshi ji 8.20a. 
as an aesthetic pursuit, an occasion to socialize, or a welcome reprieve from hard or dirty physical labor. Women's allusions to embroidery show that some viewed it as a job to be got out of the way while others considered it a badge of duty performed (p. 65)." ${ }^{, 2}$ While Mann points to the oppositional relation between embroidery and literary activity as alluded to by some women, I will show below women's common perception of the commensurability between the two. Highly indicative of the central place of this particular feminine practice among women who could write is the frequency with which the titles of their poetry collections begin with the term xiu “to embroider.” In Hu Wenkai’s catalogue, there are a total of one hundred and ninety-one collections that begin with this character, more than any other character used in the initial position. ${ }^{23}$ Among these titles, the greatest number begins with the term xiuyu "[time] leftover after embroidering." Furthermore, we also find this term embedded in the title, usually after the name of the studio, such as Peilanxuan xiuyu cao (Drafts of Poems After Embroidering in

\footnotetext{
${ }^{22}$ Mann, Precious Records, 65.

${ }^{23}$ See Hu Wenkai, Lidai funü zhuzuo kao (Shanghai: Shanghai guji chubanshe, 1985), 1020-23. Examples of other characters related to textile production and sewing used in the initial position of titles (often followed by yu) are: fang, which occurs in 4 collections, gong in 29, ren 1, zhi 20, zhen 7, cai 4, ji 3, and ji or jizhu 3. See Hu Wenkai, 983 and passim. After xiu, the next most frequent character at the beginning of titles seems to be lü (green), and in particular the term lüchuang (green window), see Hu Wenkai, 1030-31. The popularity of lüchuang—a window with a green-gauze screen — probably derives from its synecdochic reference to the dwellings of women. Women saw themselves as composing poetry and performing other feminine arts in the private space of their inner chambers.
} 
Orchid-Sash Studio) by the nineteenth-century Manchu woman poet Wen Huang. ${ }^{24}$ Gan Lirou’s poetry collection, Yongxuelou shicun, presents a particularly striking case. Gan herself arranged her poems in four juan (chapters) according to the stages of her life-as unmarried daughter, wife/daughter-in-law, widow, and mother in retirement, and named each accordingly.

Significantly, the first juan, comprising of poems she wrote when she was a daughter growing up in a gentry household, is entitled "Xiuyu cao” (Drafts after Embroidering), ${ }^{25}$ and contains many poems with references to embroidery. Beginning in her adolescence, embroidering is mentioned in juvenilia poems written as part of her everyday life in a cultured family, such as one entitled "In Leisure after Embroidering, Following Mother I Climb up the Storied Tower.,26 Gan also wrote poems on special occasions in which she inscribed embroidering as an activity in tandem with poetic composition:

\section{Matching My Elder Brothers’ Rhymes on New Year’s Eve}

While this year will end with tonight,

Next year will come with tomorrow.

Time's shuttle flies, though we are unaware,

${ }^{24}$ Hu Wenkai, Lidai funü zhuzuo kao, 813.

25 “Xiuyu cao,” with 210 poems, is followed by “Kuiyu cao” (Drafts after cooking), with 248 poems written during her married life; "Weiwang cao" (Drafts of the one who has not died), with 187 poems written in her widowhood; and "Jiuyang cao" (Drafts of one who lives with her children in retirement), with 263 poems written when she went to live with her son after he had passed the jinshi examination and obtained official appointment.

26 "I Went up to Nourishing Cloud Tower in Mother’s Company: Composed on the Scenery," Yongxuelou shicun, juan 1, “Xiuyu cao,” 1b. 
Looking at the mirror, I try to make out my reflection.

So long as we have the joy of reunion,

What harm is there to the hurrying seasons?

My new poem is completed within the candle's notch,

When I am done embroidering, I too join in the decision. ${ }^{27}$

In the last line, Gan puns on the word "decision," cai, by combining the idea of cutting cloth with scissors to make a design and making a decision or judgment about composition.

To say that one's collection of poetry was produced in the time after embroidering would seem to denote the priority of woman's work over writing (i.e., literary talent). This accords with the discourse of domesticity that Maureen Robertson has identified in prefaces written by women as the strategy that they adopted to justify their engagement with literature and writing by claiming that it took place after they had fulfilled their domestic duties, and by extension, that scholarship and literary activity complemented and formed part of women's responsibilities, particularly as capable helpmates to their husbands and as mothers who were educators of sons. ${ }^{28}$ However, I suggest that we can also give a more positive reading to the ever-present xiuyu in the titles of poetry collections as connoting a perception that writing was a womanly occupation that was as important as the canonically recognized woman's work represented by embroidering.

27 Yongxuelou shicun, juan 1, “Xiuyu cao,” 3a-b.

${ }^{28}$ Maureen Robertson, “Changing the Subject: Gender and Self-Inscription in Authors’ Prefaces and Shi Poetry," in Ellen Widmer and Kang-i Sun Chang, eds., Writing Women in Late Imperial China, 171-217. 
Because embroidering was such a ubiquitous practice for women across age, class, ethnicity, ${ }^{29}$ and region, they also sometimes named the titles of their collections by the different states or stages related to their experience of this activity. We find, for example, juanxiu ji "collection [produced] after tired by/of embroidering,” baxiu ji “collection [produced] after giving up/stopping embroidering,” and xuexiu ji “collection [produced] when studying embroidery.” The terms juanxiu “tired of/by embroidering” and baxiu “stopping/giving up embroidery” are wonderfully ambiguous and women exploited this ambiguity by using them also as titles of particular poems. In some cases, it then forms an inscription of resistance to the orthodox demands of woman's work as the women put down their embroidery or turn away from it to write about it or some other experience that has caught their attention. In a poem on the very topic of embroidery titled “Embroidering,” Li Qinghui, who is one of the women noted above for making a living by embroidering, in an ironic manner subverts the normative priority of work before literature:

I only arrange the fragrant floss, I don’t arrange my makeup, The gilded needle stops embroidering while I reflect with careNowadays I am quite weary of these trivial flowers and grasses, I turn to examine my new poems in the embroidered brocade bag. ${ }^{30}$ Constructed in the poem is a hierarchized progression moving to ever more valued and significant types of feminine activity—from self-adornment to work to creativity. The image of a brocade bag holding fragments of poems and poetic lines in the last line alludes to the legendary

${ }^{29}$ Among the forty-plus poetry collections by Manchu women, three have xiuyu in their titles. See Hu Wenkai, Lidai funü, 813-819.

${ }^{30}$ Zhengshi ji 20.17b. 
habit of the talented young Tang poet Li He (790-816), who kept half written poems and lines of poems in a brocade bag that his page carried around. Li He would later weave and complete the fragments into dazzling poetic compositions. By this allusion, Li Qinghui suggests that her serious and constant concern is with writing poetry, other types of activity that women are interested in or supposed to be engaged in are secondary. But the brocade bag containing her poems was no doubt meant to be understood as one that she herself had embroidered. Thus, by referring to or writing about this gendered specialization, women define and claim a specifically feminine but multivalent space in which is located the meanings of work, virtue, talent, aesthetics, and sociality. When some male scholars in the late Ming took up the practice of embroidery, they were inserting themselves into a recognized feminine practice in order to achieve the positive values associated with it. ${ }^{31}$

\section{The Motif of Embroidery in Poetry}

${ }^{31}$ See examples discussed by Dorothy Ko, Teachers of the Inner Chambers, 175. It follows that my reading of the few men who took up embroidery is in some ways opposite Ko's. That is, just because a few men took it up in the late Ming, it does not imply, as Ko suggests, that embroidery, "this quintessential attribute of feminine virtue was devoid of gender specificity" in some ways. The value or virtue of embroidery was produced through the material practice of women. When certain men tried to achieve the precision, concentration, and attention to detail through embroidery, it does not change the overall gendered nature of the work as nügong. A comparable reversal would be the practice of swordsmanship for women. Significantly, that women were able to contest the practice of writing poetry and claim it as their legitimate domain is precisely because poetry as self-expression cannot be demarcated by gender as easily as other forms of cultural performance can be. 
How did women write about embroidery? Can we discern any gender-specific patterns in the manipulation of this practice? Male poets tend either to give mildly erotic connotations to the image of a young girl languidly embroidering symbols of love (such as mandarin ducks and love knots), particularly in song lyrics (ci), or they write with admiration about the intricacy and beauty of women's embroidered work. ${ }^{32}$ In contrast, women textualize embroidery as an everyday activity and experience. They indeed differ markedly from male poets by inscribing the trope of embroidering with varied meanings and employ it to signify other regions of their experience, whether emotional, intellectual, aesthetic, or spiritual. Examples of poems demonstrate these appropriations. As a gendered communal or social activity enjoyed between female friends, neighbors, and relatives, embroidery connotes female friendship and bonding. In a poem recalling a neighbor who had to move to the border regions with her husband, Wang Hui (17th century) used embroidering to show how they shared an activity in each other's company: "Fragrance moistening our embroidery bags we separate threads together/In the warm spring we send flowers to each other's dressing table.”33 Similarly, a poem titled “Spring Boudoir,” by an anonymous girl from Wuxing, also inscribes sororal camaraderie in relation to embroidery: "When I finished the embroidery, I called my sisters to come and have a look/Warm breeze and bright sunshine filled the railed verandah.”34 The couplet also expresses a sense of pride in her work.

${ }^{32}$ For examples of male poets’ appreciation for women’s embroidery, see Yan Ming and Fan Qi, Zhongguo nüxing wenxue de chuantong (Taipei: Zhonghua jijin guanli weiyuan hui, 1999), 4647.

${ }^{33}$ Zhengshi ji 2.12a-12b.

34 Zhengshi ji, Fulu.7b. 
Here I would like to emphasize the materiality of experience in everyday life that effects the textualization of embroidering in women's poetry as a recurring motif. Mothers taught and then wrote about teaching their daughters embroidery. When Shen Yixiu (1590-1635) did so, her poem turned to memories of her own experience as a thirteen year-old learning the craft: "I remember when I was just over thirteen/I began to learn to embroider leaning by the bed.”35 Memories of adolescence are inscribed in poems adult women wrote when marriage separated sisters who had grown up together at home, and the activity of embroidering is often figured in their recollections. Jin Yi (18th century), one of Yuan Mei's female students, wrote a poem when her married sister left after a visit back to her natal home: “After Parting With Elder Sister I Felt Quite Out of Sorts. Moved by the Past I Narrated My Feelings in a Seven-character Regulated Verse with Sixteen Rhymes.” The usual four rhymes (or eight lines) in a regulated form seemed an inadequate vehicle for the rush of emotions and memories aroused by the reunion and parting. With sixteen rhymes (thirty-two lines), Jin Yi gave rein to her remembrance. She recited a litany of activities that she and her sister shared together as young girls, such as playing hide-and-seek, reading at night, worshiping the Buddha, writing poetry, and embroidering: "We looked at the embroidery by the window after we rose from bed/Before planting flowers we deliberated endlessly the night before." ${ }^{\text {36 }}$ Indeed, engaging in embroidery together was often among the most memorable moments of a shared girlhood. When the widowed Zhang Yuzhen found herself

${ }^{35}$ Ye Shaoyuan, comp., Wumengtang ji (Beijing: Zhonghua shuju, 1998), vol. 1, 30. See also Dorothy Ko's translation and discussion of Shen Yixiu's poem in Every Step a Lotus: Shoes for Bound Feet (Berkeley: University of California Press; Toronto: The Bata Shoe Museum, 2001), 85-87.

${ }^{36}$ Suiyuan nüdizi shixuan, in Yuan Mei quanji, vol. 7, 39. 
sleepless on a rainy night, her thoughts turned to one of her younger sisters. In inscribing her thoughts in a poem, her memory was also marked by their embroidering together: “After embroidering we would relax on the couch together/In a flash thirty years have gone by."37 In another poem in which a younger but already married Zhang Yuzhen thought of her little sister who was still at home, she wrote: "I imagine, as the days get longer, needle and thread get sluggish/Leaning in the upper story you must be thinking of me who has gone faraway."38 Chen Shulan, thinking of her Aunt Wu, sent this poem to her:

Sorting red floss I sit by the window of green gauze, Thinking of you the day feels especially long. I recall in the old days beside the bamboo curtain, Taking up needles, together we embroidered phoenixes. ${ }^{39}$ The thoughts of her aunt seem inseparable from the act of embroidering. While continuing to embroider as a married woman, the niece remembers fondly how she had performed this task in the company of her aunt. The auspicious pair of phoenixes is a symbol for a conjugal couple. The line might suggest that the aunt had helped the niece embroider part of her trousseau in preparation for marriage. As a married woman turning her attention to the next generation, Chen Shulan wrote a poem entitled "Reciting after Embroidering”:

Sitting quietly after embroidering inspires clear thoughts, Making tea, adding more incense, everything seems right.

I call my little son and daughter to the front of the steps

37 Suiyuan nüdizi shixuan, in Yuan Mei quanji, vol. 7, 70.

38 Suiyuan nüdizi shixuan, in Yuan Mei quanji, vol. 7, 67.

39 Suiyuan nüdizi shixuan, in Yuan Mei quanji, vol. 7, 97. 
And teach them how to hold needle and thread and recite poetry. ${ }^{40}$

“Xiao ernü” should refer to both little sons and daughters, which makes the gender division of the skills she is teaching them slightly ambiguous. It almost reads as though Chen Shulan is teaching her children, regardless of gender, both embroidery and poetry when in fact she would have taught her boy only poetry but her girl likely both skills. As Dorothy Ko so aptly put it, “[e]mbroidery was more than a skill that daughters learned from mothers; it was a conduit for a female culture that one generation of gentry women passed on to the next along with their emotions and dreams."41 This is particularly the case when the everyday practice of embroidery was situated within a literate and literary female community.

When writing about her happiness at her cousin’s visit, another young woman, Liao Yunjin, singled out embroidering and composing poetry as the two activities they enjoyed in their short time together:

Delighted that My Younger Cousin Gaoping Has Come for a Visit How wonderful that we know each other's interests, Laughing we talk until the last drip of the water clock.

Opening the dressing case, together we look at the almost finished embroidery, Trimming the candle, leisurely we mull over words for an incomplete poem. In the gilded censer, the word-shaped incense burns thin in the deep ashes, By the crystal curtain the wind stills, flowers delay their scattering, Now that you've come I worry that we will lightly say goodbye,

40 Suiyuan nüdizi shixuan, in Yuan Mei quanji, vol. 7, 98.

41 Dorothy Ko, Every Step a Lotus, 87. 
In the moonlight before the lamp we bind our thoughts and dreams together. ${ }^{42}$

Set in a parallel couplet, the two girls' efforts at embroidery and poetic composition are presented as equal components that make up a moment of pleasure that they partake together in their feminine space. Written when she was sixteen, Gan Lirou's series of quatrains mourning her elder sister who died at the age of nineteen are also inscribed with memories of embroidering and writing poetry as part of their sisterly intimacy, for example:

I.

Deep in the boudoir we were companions for sixteen years, After embroidering you taught me the essay by Ban Zhao. Why have you gone to Heaven to revise elegant writings, Not willing to transmit all secrets to the human realm? IV.

After needlework and embroidery the brush naturally followed, Copying by hand the poetry of a hundred famous women.

Like fair ripples your calligraphy transmits the true style, But to whom will you entrust this case full of fine compositions? ${ }^{43}$

Significantly, the linking of embroidering with poetry writing in parallel couplets is a recurrent motif in women's poems on the subject. For example:

42 Suiyuan nüdizi shixuan, in Yuan Mei quanji, vol.7, 78. This poem was also selected by Yun Zhu, see Zhengshi ji 11.19b.

43 “Weeping for Elder Sister: Another Ten Quatrains,” in Yongxuelou shicun, juan 1, “Xiuyu ji,” 20b-21a. 
Needlework and embroidery, illustrations and books,

On left and right they lie mixed together. ${ }^{44}$

Embroidering by the window I find the time too short, Mulling over a poem in the lamplight I love the slow water clock. ${ }^{45}$

To look up ancient characters I take the books out of order, To embroider more flourishing flowers I unroll a long thread. ${ }^{46}$

These couplets all emphasize the compatibility of embroidery and poetry as feminine pursuits that women enjoy and to which they devote their time and energy. By placing them side by side in the formal structure of a couplet, the task of embroidering and writing a poem are presented as equivalent. As a skill, embroidery is seen as analogous to poetic composition, both require learning, application, and talent, and the products are aesthetically pleasing. We see embroidery (and also weaving) taking on a metaphoric function as the vehicle for literary and poetic composition, particularly when women are writing inscriptional verses for the poetry collections

\footnotetext{
${ }^{44}$ Wuyunzhu, "Writing my Thoughts on a Spring Day,” Zhengshi ji 1.3b.

${ }^{45}$ Xu Zaipu, “Random Feelings on a Winter Day,” Zhengshi ji 8.19a.

46 Yuan Zhu, “Sleepless,” Zhengshi ji 9.18a. She was one of Yuan Mei’s sisters. Yuan Mei also printed his three sisters’ poetry collections jointly as Yuanjia sanmei hegao (The Combined Drafts of the Three Younger Sisters of the Yuan Family), see Yuan Mei quanji, vol. 7, 1-63 (separate pagination). This poem is found on p. 44.
} 
of other women. That women were inclined to conjoin the two arts attests to the materiality of these practices in their everyday lives and also their familiarity with the literary tradition in which the art and beauty of embroidery had been used as a metaphor for the refinement of literary composition. For example, the "Wenfu” (Rhapsody on Literature) by Lu Ji (261-303) is an early canonical piece in which the beauty of literary composition was compared to that of embroidery: “At times literary thoughts blend in a fabric/Limpid and lovely, resplendent and bright/Glistening like intricately colored embroidery."47 In a series of poems, Huang Lixiang mourned the death of Lady Scholar Ouxiang and inscribed her poetry collection entitled Xiuyu yingao (Drafts for Chanting after Embroidering) using_appropriately_images of cocoon and silk, embroidered canopy and woven scarf. In one couplet, she describes Lady Scholar Ouxiang's writing as "carved jade pendants” and "a pile of spit-out floss," the latter standing for precious words that came from her mouth. ${ }^{48}$ In the poem "Written at Random” by Tang Xiangzhi, weaving is clearly constructed as a metaphor for literary composition, or vice versa. For in the second couplet, it is difficult to separate the two activities:

Creaking creaking the nine-part loom,

Vermillion threads cross on the loom.

I finish weaving the palindrome

\footnotetext{
${ }^{47}$ Xiao Tong, Liuchen Wen xuan huizhu shujie (Taipei: Zhengda yinshu guan, 1974), vol. 2, juan 17.11a; translated by David Knechtges, Wen xuan, or Selections of Refined Literature (Princeton: Princeton University Press, 1996), vol. 3, 223. I am grateful to one of the anonymous readers for pointing out this early example.

${ }^{48}$ Zhengshi ji, 17.22b.
} 
Composition belongs to the women's quarters. ${ }^{49}$

We have seen how women wrote about the practice of embroidery as a shared, social activity between women, but they also wrote about it as a solitary activity performed alone. This dimension of the experience of embroidery leads to interesting developments in their poetry. Practiced alone in the quiet of the inner quarters, the concentration and the repetition of the stitching take on a meditative, religious quality. It is a feminine activity that fits into a contemplative mode:

On a Summer Day: Dwelling in the Mountains

The hills are quiet, as is right for hot weather, Wind through the pines enters into my clear dream.

Rain colors fly across precipitous cliffs,

On ancient trees sob the sound of cicadas.

Stitching embroidery has been my lesson in recent years,

Watching clouds produces sentiments beyond phenomena.

If one does not know that the dusty world is faraway,

In vain one will try to prove No Rebirth. ${ }^{50}$

From the aesthetics of poetic craft, this regulated piece by Yan Liu would be judged a poor imitation of the High Tang poet Wang Wei's Buddhist-inflected "nature” poems. She has the required rhymes and tonal antithesis; the prescribed parallelism of the second and third couplets is largely met on the syntactic but not quite on the semantic and grammatical level. She borrows

${ }^{49}$ Zhengshi ji 19.18b.

${ }^{50}$ Zhengshi ji 1.20b. 
freely from the well-known vocabulary and syntax of Wang's famous regulated verses: the sound of wind through the pines, watching clouds, beyond phenomena, and the verb ye (sob, choke), including inverting its syntactic position with the subject "sound of cicadas." But the one thing that is new in this poem is the practice of embroidery and its seemingly natural place in a woman's life of contemplation.

To carry out the minute and meticulous work of embroidery requires patience, concentration, and diligence. It requires bodily and visual discipline: sitting for long hours at the embroidery stand or holding the embroidery loop, and looking closely at the evolving design as the fingers perform fine stitching on the surface. It is an activity that entails endless repetition. It is through the analogy of repeated practice, discipline, and concentration that embroidery takes on religious meanings. Its practice is in some ways akin to religious recitation, the accumulation of merit through endlessly repeating the name of the Buddha, and chanting or copying a sutra. Similar to women's pairing of embroidery with poetry as a fine craft and creative performance, women also paired it with religious practice. Embroidering images of the Buddha, in particular of the Bodhisattva Guanyin, became a popular act of religious devotion for women (figure 3). And some women embroidered them with their hair. ${ }^{51}$ This spiritual practice too, like the hard work of the widow weaver, appears frequently in women’s biographies. In a biographical poem about a filial daughter surnamed Ma who remained unmarried to bring up her nephew, the woman poet Dong Xuehui wrote: "Embroidering Buddhas and keeping to a vegetarian diet she has already spent half her life/The human realm is separated from Heaven but her absolute sincerity can reach through., 52

${ }^{51}$ See Susan Mann, Precious Records, 182-183.

${ }^{52}$ Zhengshi ji 9.7a. 
According to the biographical note on Sun Xuying, whose father did not have a son, Sun was determined not to marry but to support her father in his old age by means of her embroidery. Sun Xuying ends her poem entitled "Writing my Feelings" with the couplet: "In recent years I have thrown away most of my embroidery patterns/What remains is the portrait of the Great Bodhisattva of Spiritual Mountain.”53 That women embroidered images of Buddhas and Guanyin is attested to also by poems they inscribed on such works. Shao Qiaoniang, for example, has a poem entitled "Inscribed on the Painting 'Shancai Paying Homage to Guanyin' that I had Embroidered":

Her appearance like flowers, her face like jade-I see her compassionate heart, The precious raft lying across the sky is hidden behind the bamboo grove.

There is a ford in the Southern Sea, but who will ferry me across?

So I have embroidered a child making obeisance to Guanyin. ${ }^{54}$

The precious raft is a Buddhist metaphor for the teachings of Buddha that will carry sentient beings to the shore of enlightenment. It seems that Shao Qiaoniang views her act of embroidering a religious picture of a child worshiping Guanyin as a meritorious deed that will help her achieve salvation. The child could also be an ideal image of the self that she has created. This poem exemplifies how the acts of embroidery, religious devotion, and self-expression are unified in the everyday life of some women. Women correlated the act of repetition in learning and practicing embroidery, the concentration and devotion required to master and perfect the skill, and the setting or environment of embroidering with their religious and literary activities.

\footnotetext{
${ }^{53}$ Zhengshi xuji 3.2a.

${ }^{54}$ Zhengshi xuji 4.19b.
} 


\section{Discourse on Embroidery: Knowledge and Aesthetics from the Female Hand}

The verses examined in the first section show that writing about the practice of embroidery in poetry was closely connected to the everyday experience of many educated women in late imperial China. Women construed themselves and other women in poetic discourse as subjects who performed two significant and related activities in the women's quarters that had economic, social, aesthetic, and spiritual value. The dominant discourse of poetry in Chinese culture, while conferring a degree of self-empowerment on the writer, constituted essentially a personal, selfexpressive medium available to ever increasing numbers of men and women in the late imperial period. Among the many women conversant with poetic composition, a few also gave voice to their practice and experience of embroidery by writing a prose treatise on the subject. In doing so, they demonstrated their knowledge of the field and expertise in the craft. Treatises and manuals constitute a discursive field that presumes in some measure not only talent, skill, and specialization, but also a sense of authority on the subject. It is in relation to women's position of expert authority in the changing cultural and economic landscape of the late imperial and early republican periods that I turn to examine the three treatises on embroidery produced by women. 1. Aestheticizing Embroidery: The Cixiu tu (Illustration of Embroidery)

Given the conjunction of several factors-increasing female literacy, embroidery as a gendered knowledge field based on practice, and the publishing boom of the period, it is not surprising that the late Ming witnessed the first recorded publication of a small work on embroidery by a woman, the Cixiu tu. However, nothing appears to be known about its author Zhang Shuying; we have no information concerning her family, marriage, or the specific time period in the Ming, or earlier, when she might have lived. Her native place is given as "Wu," the area of Suzhou, which, alongside Nanjing and Hangzhou, was one of three major textile 
production centers in the Ming and Qing. Suzhou is also well known for its fine embroidery and regularly supplied the imperial court in the Qing.

The Cixiu tu is included in late Ming collectanea and encyclopedic compendia to practical matters in everyday life (leishu), such as the Lüchuang nüshi (Women Scholars by the Window of Green Gauze) $)^{55}$ and some editions of the Jujia bibei (Essential Guide for Home Life). ${ }^{56}$ While being included in the latter compendium attests to the practical usefulness that this

${ }^{55}$ See n. 23 on the feminine connotations of lüchuang. I use the late Ming edition printed by the Xinyuan tang in the Harvard-Yenching Library, which is the same edition as the copy in the National Library in Taipei. For the table of contents, see Zhongguo congshu zonglu (Rpt., Shanghai: Shanghai guji chubanshe, 1986), vol. 1, 58-60. In her study of how women and female matter are categorized in leishu (encyclopediae), Harriet Zurndorfer mentioned that this collectanea was first compiled by Yang Weizhen (1296-1370). See "Women in the Epistemological Strategy of Chinese Encyclopedia: Preliminary Observations from Some Sung, Ming, and Ch'ing Works," in Harriet Zurndorfer, ed., Chinese Women in the Imperial Past: New Perspectives (Leiden: Brill, 1999), 373-74. Contrary to the information she received from Christian de Pee regarding the edition of the Lüchuang nüshi in the National Library, it does not contain the type of illustrations she mentioned on p. 374 .

${ }^{56}$ See the table of contents for the edition with 98 titles and, according to the editorial note, a preface by Qu You (1341-1427), in Zhongguo congshu guanglu (Wuhan: Hubei remin chubanshe, 1999), 1.162-63. As one of three texts by women, the Cixiu tu is shown as placed after the Nüjie and Nü xiaojing. I have not had access to this edition. Its inclusion in the Jujia bibei is also noted by Wang Shilu (1626-73) in his Gonggui shiji yiwen lüekao, see Hu Wenkai, Lidai funü zhuzuo kao, 158. 
small treatise was thought to have, its feminine and aesthetic value also makes it a fitting piece in the former collection, which seems to partake in the late Ming market for the commodification of writings by and about women. ${ }^{57}$ The Lüchuang nüshi was compiled by a person who identified himself with the pseudonym Qinhuai Yuke, "Visitor of the Qinhuai,” naming himself after the famous pleasure quarters in Nanjing. Printed (or reprinted) sometime during the late Ming, probably in the Chongzhen reign (1628-1644), this collectanea is devoted to various genres of writings by and about women. Although it includes four standard didactic texts for women—-the Nü lunyu (Analects for Women), Nü xiaojing (Classic of Filial Piety for Women), Nüjie (Precepts for Women), and Nüfan (Models for Women), judging from the preface penned by Qinhuai Yuke, it appears that women were not necessarily the only intended audience. In highly ornate parallel prose, Qinhuai Yuke first catalogues various occasions and historical precedents of feminine literary and artistic production (among both elite women and courtesans) before concluding with this remark: "These occasions are indeed wondrous events among ladies. Furthermore, we can smile upon their leisurely compositions on silk. No one should make fun of them (or 'me')." ${ }^{58}$ The preface seems to be addressing itself to a male readership, suggesting to them a light and paternalistic attitude towards this literature by (or about) women. The first nine out of the ten section headings (bu) in the Lüchuang nüshi are based on typologies of women: 1 . Guige (Women in the Inner Quarters, i.e., gentlewomen), 2. Gongwei (Women in the Palace), 3. Yuan'ou (Fated Lovers), 4. Minggan (Lovers from Illusory Realms), 5. Yaoyan (Seductive

\footnotetext{
${ }^{57}$ I discuss this issue in relation to late Ming anthologies of women's poetry, see "CounterCanon Effects: Anthologizing Women’s Poetry in the Late Ming,” Chinese Literature: Essays, Articles, Reviews 26 (December 2004, forthcoming).

${ }^{58}$ Lüchuang nüshi yin,” 1a-2a.
} 
Fairies and Demons), 6. Jiexia (Martyrs and Warriors), 7. Shenxian (Immortals and

Transcendents), 8. Qiebi (Concubines and Maids), 9. Qinglou (Women of the Pleasure Quarters), and 10. Zhuzhuan (Authored Works). While the collection consists of biographical, fictional, and anecdotal writings about women, the last division — explicitly titled Zhuzhuan "Authored Works"-is the single largest category, comprising more than forty selections of writings by women in more formal prose genres such as edicts, memorials, letters, and eulogies dating from the earlier dynasties, from the Han to Tang, with two pieces from the late Ming. ${ }^{59}$ Significantly, the Cixiu tu is located in the first section "Guige," or "gentlewomen of the inner quarters." This section is subdivided into four categories: Yifan (Models of Womanly Virtue), Nügong (Woman's work), Caipin (Talent and Character), and Rongyi (Deportment), which approximate the four canonical feminine virtues of morality, work, speech, and conduct. Zhang Shuying's Cixiu tu is appropriately included in the section "Woman's work," and is the first of four texts, followed by the famous woven palindrome Zhijin xuanji tu by Su Hui (pre-Qin); a cookbook, entitled Zhongkui lu (Records of One Who Manages the Cooking), by a woman surnamed Wu; and Can jing (Classic on Sericulture), a treatise on how to raise silkworms by Huang Xingzeng, a male author, also identified as from Suzhou.

${ }^{59}$ One is the much anthologized preface by the "Girl from Kuaiji,” believed to have been originally written on the wall of an inn to accompany her poem (under the subsection "Xu zhuan” in juan 14). This preface and poem date from around the Tianqi period (1621-1627) and are included in contemporary anthologies of women’s poetry such as Zhong Xing’s Mingyuan shigui, Qian Qianyi’s Liechao shiji (Runji), and, a little later, Wang Duanshu’s Mingyuan shiwei. The other work Hua suoshi consists of a series of short anecdotes involving women and flowers by the famous late Ming courtesan Xue Susu (under the subsection “Zalu”, in juan 14). 
Whatever the original context of its production, the subsequent placement of Cixiu tu in late Ming collectanea shows that the text was regarded as exemplary of, and instructive in, one specialization of woman's work, along with weaving, cooking, and sericulture. The text of the Cixiu tu is extremely brief; it consists of eight terse passages with the following headings: 1. Pin (Character), 2. Tu (Subjects), 3. Fa (Methods), 4. Zhi (Materials), 5. Qi (Implements), 6. Gong (Accoutrements), 7. Ji (Occasions), and 8. Hou (Seasons).

Essentially, it posits embroidery as an art practiced by elite women and provides practical as well as prescriptive advice on the subject. The first passage on "character" states that embroidery can be taken up by women who have a kind personality and good disposition, are far above the vulgar in manner and deportment, and are cultivated and refined. ${ }^{60}$ The ideal embroiderer is defined through a series of attributes that imply class and proper upbringing. The third passage on "methods" explicitly compares embroidery to calligraphy and painting, the twin arts of literati culture. The desired variations in applying the needle are likened to the complexity of calligraphy and the varied density of the stitches is likened to a painter drawing living objects; the passage concludes by stating that embroidery “is not just women’s needlework." 61 The subjects that are listed as appropriate examples appear to be selected from an established repertory for embroidery, including the image of the Buddha, mythical female figures, landscapes, seasonal scenery with architecture, butterflies, and specific birds and flowers. These clearly mirror genres and categories in painting. We can infer the ideal setting or environment for embroidering from the sixth passage which lists accoutrements that would be in the possession of an elite household with wealth and taste: famous incense, flowers in a vase,

60 Cixiu tu, 1a.

61 Cixiu tu, 1b. 
painted standing screens, lacquered table, emerald-green gauze that is [thin] like mist, rose water, towel for wiping [hands], and young maids. ${ }^{62}$ This passage implies that one does not simply sit down to embroider, rather, proper preparation and the creation of an aesthetic, almost religious, environment (for example, by burning good incense) should be carried out first. The three occasions considered suitable for embroidering are said to be during fasting and purification (again with religious and ritual connotations), convalescence, and when tired. These are occasions when a woman would be by herself in a quiet environment undisturbed by the usual hustle and bustle of mundane activities, and embroidery was also considered a purifying as well as a palliative activity. This spiritual aspect of embroidering recalls its strong association with religious devotion in women's lives that we have observed above in their poetic writings on the subject. The final passage lists the optimal time in the different seasons for doing embroidery: a fine day with warm breeze, long nights in autumn, in the spring chill, when flowers hang over the railing, when the shadows of bamboos show on the window, when swallows enter through the curtains, and when the $x i$-spiders hang from the towels. ${ }^{63}$ The appearance of the last three is a marker of spring: growing bamboos, returning swallows and $x i$-spiders. The $x i$-spiders, whose name is a homophone for happiness, are also regarded as an auspicious omen. Winter is conspicuously absent since its harsh cold impedes the dexterity of the fingers. As the Buddhist devotee Tao Shan (1756-1780) recounted explicitly in her poem "Impromptu Composition on a Winter Day": "When winter arrives, I put aside embroidering/And chant a verse, sitting quietly

${ }^{62}$ Cixiu tu, 1b-2a. I am uncertain about the punctuation of the passage and thus the list of items. ${ }^{63}$ Cixiu tu, 2a. 
next to the brazier." ${ }^{64}$ After putting aside women’s work, Tao Shan turns to ponder on the state of chan meditation in the remainder of the poem.

In spite of its brevity and succinctness, Cixiu tu effectively conveys an elite, gendered view of embroidery. This view not only comes across in the brief statement on the "methods" of embroidery that compares it to the art of painting and calligraphy, and the attention and emphasis it gives to creating the ideal conditions for embroidering over practical and technical instructions, but the writer's cultivated stance is also suggested through adopting a poetic, somewhat elliptical mode of rendering, rather than through matter-of-fact description or explication. The effect is a certain aestheticization of the subject and the text itself. Elite women were as capable of aesthetic imagination as their male counterparts. They elevated a type of work that, depending on a woman's social class, was performed in diametrically opposed environments and for completely different purposes — embroidery could be undertaken for livelihood or for pleasure, just as painting could for literati in the late imperial period.

\section{Articulating the Gendered Social and Aesthetic Space of Embroidery: Ding Pei’s Xiupu}

In the Xiupu written by Ding Pei, there remains the elitist, gendered aestheticization of embroidery. But the text and especially the contexts differ in significant ways from the Cixiu tu. The text itself is more detailed in technical explanation, more complex in elaborating its conception of embroidery, and richly multidimensional when viewed in its contexts, which derive from information both internal and external to the text. Contrary to the void surrounding

${ }^{64}$ Zhengshi ji 13.12a. On the religious bent in the life and poetry of Tao Shan, see the study by Beata Grant, “Who is this 'I’? Who is that 'Other'? The Poetry of an Eighteenth Century Buddhist Laywoman,” Late Imperial China 15.1 (1994): 47-86. This poem is cited in full on p. 54. 
Zhang Shuying's identity and the provenance of her text, Ding Pei not only identifies herself in family contexts—both natal and marital, she also locates herself as a participant in women's social groups through the technology of writing. Her connections to other women are corroborated by her biographical entry in the monumental work on women poets of the Qing, the Mingyuan shihua (Remarks on Poetry by Notable Women; preface 1845), by the woman poet and writer Shen Shanbao (1808-1862), who was Ding Pei’s friend: ${ }^{65}$

Ding Bushan (Pei) of Yunjian ${ }^{66}$ and I were friends in spirit for seven years before we were able to meet for the first time. During those seven years, our communication was never interrupted. When one chanted, the other would harmonize. It was as good as chatting in the same room. She has published the Xiupu. She is also an exceptional letter writer. I still recall the first time she sent me a letter, which she entitled "News of the Plum Blossoms.” [The letter is quoted at length. ... .] Bushan is the wife of Chen Liangqiao (Yugang) of the Ministry of Personnel, who was a native of Lanxi. When Liangqiao went to take the metropolitan examination in the spring, Bushan sent him a poem with the lines: "On the path I do not notice the green of the willows/From the upper

${ }^{65}$ On Shen Shanbao and the Mingyuan shihua, see Grace S. Fong, "Writing Self and Writing Lives: Shen Shanbao’s (1808-1862) Gendered Auto/Biographical Practices,” NAN NÜ: Men, Women and Gender in Early and Imperial China 2.2 (2000): 259-303; and "Imagined and Real Communities: Shen Shanbao’s (1808-1862) Critical Discourse on Women’s Poetry,” paper presented at the Annual Meeting of the Association for Asian Studies, Washington D.C., April 47, 2002.

${ }^{66}$ Ding Pei’s native place Yunjian is also known as and referred to by several other names: Huating, Songjiang, and Sanmao. 
floor I only hope for the red apricot blossoms.” These lines were widely recited by people. Regrettably, one year after Liangqiao obtained the jinshi degree, he died in the capital without leaving an heir. Bushan brought up their three daughters, relying on doing woman's work [embroidery and sewing] for support. I feel saddened by the straitened circumstances she encountered. ${ }^{67}$

Working on the Mingyuan shihua in the early 1840s, Shen Shanbao wrote this entry more than twenty years after Ding Pei penned the preface for the printing of the Xiupu in 1821. During the interim, Ding Pei’s husband died in 1833. Although Ding Pei wrote a preface for Shen Shanbao’s first poetry collection published in 1836, after Shen Shanbao left her hometown Hangzhou and moved to Beijing in 1837, where she married shortly after, they seemed to have lost contact with each other. In Ding Pei's own account of the origin of her work, she revealed that Shen Shanbao had been a catalyst in the publication of the Xiupu. The manual was written intermittently when there were free moments left after embroidering (giving yet another productive meaning to xiuyu—from practice to discourse), but Ding Pei had not shown her text to others. She testifies with self-deprecating modesty in her introductory remarks (liyan) that it was due to the request made by two women friends—one senior and the other junior — that her work was made “public.” As she put it, "Recently because Madam Jin Tingqiu of Yuanhu and younger sister Shen Xiangpei (Shanbao) of Wulin wrote letters to ask for it with such earnestness

${ }^{67}$ Shen Shanbao, Mingyuan shihua, 7.3a-4a. 
that I felt I could no longer hide my clumsy writing and so sent each of them a copy."68 Both Shen Shanbao's record and Ding Pei’s own words show that women friends and circles were aware of and communicated about each other’s skill in embroidery.

These two nineteenth-century women moved in the same social and cultural space as the women whose poetry on embroidering we have examined above. Their friendship, however, clearly goes beyond the limits of affective kinship ties we have seen expressed so strongly in women’s poems on embroidering. Furthermore, Shen Shanbao’s account of Ding Pei and her daughters provides a precious example, one through first-hand knowledge, of women who employed their superior skill in embroidery as a means of self-support after a husband's untimely death. That these women were able to derive income through this particular skill provides further evidence of embroidered objects as valuable commodities in the daily and ritual life of late imperial Chinese culture. $^{69}$

68 Ding Pei, “Liyan,” in Xiupu, 2a; in Congshu jicheng xubian, vol. 79, 795. I have not been able to identify Jin Tingqiu. Shen Shanbao would have been a thirteen year-old adolescent girl at the time.

${ }^{69}$ Dorothy Ko suggests that the Gu family business started in the Late Ming already exemplified the commodity market for embroidery as art, see Teachers of the Inner Chambers, 173-75. However, neither the separation of embroidery as “artistic creation” from embroidery as “economic production” nor the consequent "bifurcation of women into economic producers and cultural producers” were as clear-cut and definitive as Ko presented (175). Until the end of the imperial period in 1911, the growing demand for embroidered products in everyday contexts in fact increased the economic potential for widows and other women of scholar-gentry families of 
In addition to its significance as a textual site evidencing women's shared experience of embroidery, the Xiupu is also important for our reading of pre-modern subjectivity. Ding Pei herself penned a short preface (zixu) to her work, which I quote in full for discussion:

Work is the last of the four [womanly] virtues; embroidery is furthermore only one skill among woman's work. The fact that the ancients did not write a manual for it is because it was not considered sufficiently important. Yet, for women there is nothing better than embroidery for cultivating one's nature and emotion (xingqing). It can make those who delight in activity become tranquil; those who love to talk become quiet. Relying on it one gets rid of laziness and puts to rest confusion. One concentrates one's attention single-mindedly and contemplates principles with a serene mind.

Certainly not only are important [pieces] displayed in the ancestral shrines and insignificant ones ornament a little bag or handkerchief, but all [embroidery] partakes of the glory of official and imperial sacrificial robes and takes inspiration from flora and fauna. As for learning from the Creator to endow form and investigate the qualities of the ten thousand things, [embroidery] reaches similar wonders as the calligraphy of talented men and the paintings of famous masters. But practitioners often quit out of boredom and frustration because they are not able to find a method to follow and to examine the trends. Why should we be confounded by the fact that it is rare to encounter those who excel in this art?

I dwelt in Sanmao in my youth. When I grew up, I went in marriage to Shuangxi. In the time left over from waiting on my parents-in-law and managing the kitchen, I

moderate means to supply their own needs or to supplement the family income by their own embroidery. 
would take up needle and thread in endless enjoyment, without ever tiring. I have put together a number of entries that came from my limited experience and from what must be changed in common practice and collated them into one chapter (juan). If I am criticized by divine experts of the needle and female embroiderers of the world for writing a piece that is not up to the standards of elegance, I can only say that this is just meant as an aid to woman's work. Recorded by Bushan, Ding Pei, who went to Yingchuan in marriage, on the day before the Double Seventh, in the year Xinsi of Daoguang (1821), at the Yulou Official Lodging. ${ }^{70}$

To be sure, Ding Pei wrote from within the accepted, orthodox ideological construction of the virtuous woman. Her preface begins by arguing for the importance of embroidery for women by locating it within the canonical four womanly virtues, and by pointing out its efficacy in character-building by transforming unacceptable womanly behavior, such as loquaciousness and sloth, into the desirable feminine qualities of stillness, silence, and productiveness. However, in spite of the careful orthodox framing, her arguments move out of the prescribed and circumscribed gender ideal of the feminine into modes of cultural practice that construct subject positions of discernment and independent judgment. Taking a similar view as that expressed in Zhang Shuying’s Cixiu tu, Ding Pei conceives of embroidery as an art on a par with the high literati arts of calligraphy and painting. It is worth noting that she also imputes to the practice of embroidering a meditative, almost spiritual quality: “One concentrates one’s attention singlemindedly and contemplates principles with a serene mind.” And, in concert with other women who emphasize the parallel creative acts of embroidery and poetry, Ding Pei makes explicit the

${ }^{70}$ Xiupu, “Zixu,” 1a-b; in Congshu jicheng xubian, vol. 79, 795. 
creative potential of embroidery for women: "As for learning from the Creator to endow form and investigate the qualities of the ten thousand things, [embroidery] reaches similar wonders as the calligraphy of talented men and the paintings of famous masters.” In the midst of her modesty, Ding Pei is noticeably assertive as an author of, or authority on, the subject. When she expresses concern over how some women are misguided in giving up embroidery because, unlike the well established canons of male painters and calligraphers, there are no masters of this art known to them as models for emulation, she leads her readers to reflect critically on the anonymity of accomplished embroiderers—ordinary women who practice in the space of the inner quarters segregated from public recognition and acknowledgement. In this way, the text barely contains the contradictory positioning of women as subjects of ideology and practice. Finally, Ding Pei is also assertive in her mission to provide a useful guide to embroidery that is not, as she notes emphatically, concerned with the elegance of writing style. ${ }^{71}$ She posits her work as the first manual on this feminine craft. $^{72}$

Ding Pei organizes her text into six sections, each with further topical subdivisions: 1. Zedi (Choice of Location), four subdivisions; 2. Xuanyang (Choice of Patterns), eleven subdivisions; 3. Qucai (Selecting Materials), six subdivisions; 4. Bianse (Distinguishing Colors), seventeen subdivisions; 5. Chenggong (Assessing the Work), seven subdivisions; and 6. Lunpin (Evaluating Rank), eight subdivisions. The first four sections are more practical in orientation;

${ }^{71}$ She is a capable stylist in the mannered parallel prose considered elegant and often de rigueur for prefaces. See the long preface she wrote in 1836 for Shen Shanbao's poetry collection, Hongxuelou shixuan chuji.

${ }^{72}$ Ding Pei did not know of Zhang Shuying's Cixiu tu. This may have been due to the fact that the collectanea Lüchuang nüshi and Jujia bibei were not widely accessible in the Qing. 
the last two more concerned with aesthetic criteria. While she covers some of the same issues as those found in the Cixiu tu, such as environment, materials, and implements, her emphasis and approach are quite different. Ding Pei is much more elaborate in her description and explanation and thus gives the effect of a hands-on discussion in the manual. For each section, an introductory passage illustrating the fundamental significance of the topic precedes the components into which it is subdivided for further amplification. For example, in "Choice of Location,” she lists the four components: xian (unhurried, calm quality), jing (tranquility), ming (brightness), and jie (cleanliness). When discussing the importance of xian, the first component of location, she emphasizes both the internal state of mind and the external condition of being unhurried and relaxed. Thus, the reader apprehends "location" as both physical and mental space, and how environment, body, and mind interact. Under ming, she goes into great detail on where and how one should sit and hold the embroidery loop in relation to the source of light, the window. Her advice seems commonplace and commonsense enough, but it calls to mind the truism about how one should sit when one is reading or writing so that the source of light comes from the left (if one is right-handed), or, nowadays in ergonomics, how one should sit at the computer in order to align properly one's vision with the screen.

Several outstanding features in content and rhetoric in Ding Pei's text also cohere in a consistent effort to “author-ize” embroidery as women's art, one that is far from a trivial or minor craft but equal in status to elite male cultural practices. By comparison to a variety of arts and skills, in particular painting, calligraphy, and literary composition, the text repeatedly emphasizes embroidery as a difficult, demanding art that requires training and superior talent. The aim is to show the expertise, concentration, and discipline required in embroidery: 
Painting and calligraphy can both be dashed off when one is inspired. However, embroidery is accomplished by accumulating silk strands. Even when one strand is missing, the whole piece will be diminished. Therefore, it is more difficult than the other arts. $^{73}$

When historians narrate events, they can be concise but still embracing. When famous masters paint a picture, it can be complicated but not confused. These are examples of strength in arrangement (jiancai zhi li). However, in writing a composition there is the method of echoing; in applying paint there is the differentiation of distance. This is not the case in embroidering. [She then elaborates its greater complexity.] ${ }^{74}$

In learning embroidery one must begin with flowers and plants. It is comparable to beginning with the Great Learning and the Doctrine of the Mean in studying, with the standard script (zhengkai) in learning characters, with the five-character quatrain in reciting poetry, and with the qing and shang modes in playing the qin. It seems easy but is actually difficult, but through what is difficult one manifests one's skill. ${ }^{75}$

To paint landscape is comparable to composing ancient prose. One should have ready the methods for structure and vitality, coherence and continuity. This is what painters say. But it is in fact the same in the matter of embroidery. ${ }^{76}$

\footnotetext{
73 “Zedi: Xian,” Xiupu, 1a; in Congshu jicheng xubian, vol. 79, 796.

74 “Xuanyang: Jiancai,” Xiupu, 3a-b ; in Congshu jicheng xubian, vol. 79, 797.

75 “Xuanyang: Huaguo caomu,” Xiupu, 5a ; in Congshu jicheng xubian, vol. 79, 798.

76 “Xuanyang: Shanshui renwu,” Xiupu, 7a ; in Congshu jicheng xubian, vol. 79, 799.
} 
It is not difficult to see why painting in particular would provide an apt analogy for embroidery. In addition to its role, as a high art, in promoting the status of embroidery, it provides a neat parallel for embroidery in working with a framed visual and pictorial space. Many genres and subjects overlap for embroidery and painting. In making the case for embroidery, although Ding Pei often presents painting and calligraphy as arts that are implicitly gendered male in opposition to the feminine-gendered art of embroidery, the text in fact addresses its female readers as those who are already conversant with the underlying principles and perhaps skilled in the techniques of these male arts. In fact, as is commonly known, women of Ding Pei’s social class were often trained in poetry, calligraphy, and painting. The potential subtext is that these educated women were more interested in practicing painting and calligraphy than embroidery, and Ding Pei’s text on some level attempts to correct this trend: ${ }^{77}$

Consider the needle as your brush, the white gauze as your paper, silk floss as your red and black, white and yellow ink. The materials are extremely spare, but their uses are broad. Embroidery is the writing of the women's quarters. If you want to be expert in it, you must first sharpen your tools. ${ }^{78}$

Finally, from the point of view of the construction of a subject position, these passages can be read not only as analogical arguments to elevate the artistic and cultural significance of embroidery, they also serve to reinforce the reception of the authorial position by showing broad

\footnotetext{
77 This scenario was probably the cultural reality when Ding Pei was writing in the early nineteenth century.

78 “Qucai [opening passage],” Xiupu, 7b-8a; in Congshu jicheng xubian, vol. 79, 799.
} 
erudition and knowledge of privileged fields of learning and cultural practice. This authorial position is strengthened by the connoisseurship exhibited in section five and the aesthetic evaluation of embroidery in section six, which divides embroidered works into eight categories, of which the first four appear to be ranked in ascending order, and the last four not necessarily ranked: neng (capable), qiao (skilful), miao (marvelous), shen (divine), jinggong (expert), fuli (lush and beautiful), qingxiu (simple and natural), and gaochao (exalted).

A second feature of the Xiupu that is suggestive of literate women's growing sense of subjectivity is the autobiographical insertions in the text, which serve to make explicit the personal dimension that underlies women's textual production. By orienting the reader's approach to the text, the preface and introductory remarks, as we have seen, constitute an important part of this personalizing feature. While in the text of the manual, Ding Pei generally adopts a rhetoric of objective description and presentation, in several places she makes reference to her own experience when making a point. For example, in the section on "Sun, moon, clouds, and roseate mists," she attempts to show the difference between yun (clouds) and xia (a diaphanous roseate mist at dawn or dusk) in embroidery. Unlike other objects, Ding Pei writes, there is no fixed color to be used for embroidering clouds, and no particular color can be used to embroider xia: "When xia is embroidered, people will simply call it clouds." But she describes a successful example that she herself had come across:

I once saw an embroidered painting in the collection of a wealthy family. In the foreground, lake-colored silk was used to represent the river. At the top, a muted red silk was used for the roseate mists (xia). In the middle section were embroidered green peaks 
to conceal where the joints were. Hanging in the central hall, it was just like roseate mists in the sky over the river. ${ }^{79}$

On the topic of “Landscapes and figures,” she also breaks into personal reminiscence:

I remember one year on a spring day, when my boat crossed Liang Creek, the sunrays at dusk covered the mountains, and the light of the mist turned multicolored. In a playful mood, I embroidered [the scene] with faded red blended with ivory-colored floss. A row of distant hills; the fresh green color of the shanjiao trees formed a grove, and fish came to the emerald waters of the creek. Suddenly my senses were completely refreshed. This is where painters have not reached. ${ }^{80}$

The act of embroidering the natural scene shifts into an active appreciation of nature. We are not sure of where one act ends and the other begins. With an embroiderer's acute vision, Ding Pei claims that the scene she witnessed (and perhaps also embroidered) is unmatched by those produced by painters. In another example with a more practical turn on the topic of needles and scissors, Ding Pei muses, "Needles are produced in my home district Song [jiang]. At first, I did not know how wonderful they were. Later, when I traveled to Yan, Yu, Qi, and Liang, ${ }^{81}$ and used those made in other places, I found that they just did not feel right in my mind or to my hand. Only then did I realize that the reason why the needles made in Song[jiang] are so marvelous is because they are bright, straight, thin, and sharp. [She then explains what she means by each

\footnotetext{
79 “Xuanyang: Ri yue yun xia,” Xiupu, 4b; in Congshu jicheng xubian, vol. 79, 797.

80 “Xuanyang: Shanshui renwu,” Xiupu, 7a-b ; in Congshu jicheng xubian, vol. 79, 799.

81 Ancient names for Beijing/the North, Jiangxi, Shandong, and Shanxi.
} 
quality.] ${ }^{\prime 82}$ The irruption of the autobiographical voice illuminates the dimension of the personal and everyday that underlines the production of this text, which touches on the most sublime judgments as well as dwells on the most mundane details in the womanly art of embroidery.

The final point I want to make regarding the Xiupu is how its authorial voice becomes an "enabling" authority to other women, however local that effect might have been ${ }^{83}$ Within a delimited, practical field of knowledge, it instructs women on the subject of embroidery, something they all practiced to some degree in their daily life. Its language and rhetoric position women as literate and knowledgeable cultural producers. Its coaching encourages women to be creative, to make their own judgment and decisions regarding what and how to embroider. Sometimes this is done explicitly: "Categories such as grasses, a sprig of cut flowers, bees, butterflies, animals and birds all can be entered additionally, subtracted, or increased according to what you consider suitable. ${ }^{84}$ Ding Pei wants to claim a field of knowledge and practice for women that would be equal to, if not superior to men's achievements. Again from the passage on "clouds," after saying that there is no fixed color for embroidering clouds, she continues:

This is where you can employ your talent in embroidery. The cloud on the official garment against the background of the sky glows solemnly, having come into being in a

82 “Qucai: Zhenjian,” Xiupu, 9a; in Congshu jicheng xubian, vol. 79, 800.

${ }^{83}$ Because we do not have information regarding the original print run and circulation of the Xiupu, by "local” I suggest several possibilities: the small circle of women friends, such as Shen Shanbao and Jin Tingqiu, with whom Ding Pei interacted; women readers of her own and later times who came into contact with her work, one example of which is discussed below; and the inclusion of her work into collectaneas compiled by male scholars, whereby it is preserved. 84 “Xuanyang: Dianzhui,” Xiupu, 3b; in Congshu jicheng xubian, vol. 79, 797. 
civilized age. The profound plan on the imperial robes is displayed radiantly in sagely rule. Is it only literati and scholars with their ornamented brushes in vermilion courts who can make much of little and brag about their elegant thought and florid speech? ${ }^{85}$

After elaborating on the most elevated forms of embroidered cloud motifs found on official robes of the highest rank and ceremonial robes worn by emperors, which Ding Pei assumes to be the products of women's work, she poses a wonderful rhetorical question that employs a most fitting metaphor. She uses the expression jinxin xiukou, literally "brocade heart and embroidered mouth," with its vivid image of beautiful weaving and embroidery and its figurative meaning of “elegant thought and florid speech" to question the privileging of men's literary talents, and by implication, to argue for recognition of women's talent in embroidering.

Though we have little information on the reception or effect of Ding Pei’s Xiupu, a colophon by Jin Xiang (nineteenth century) included in the extant version of the text offers some specific evidence:

Ever since I learned to embroider as a young woman, I would collect the best patterns and turn them over in my hands over and over again. In my mind I know they are marvelous but I cannot express in words why they are marvelous. Even when I seemed to have made out something, I would still be beset by doubt. After several years, I only seemed to have become clumsier. Now when I read this work, I found the discussions therein skilful, detailed and well organized. For example, I can follow to a small degree the entries "Choice of Patterns" and "Selecting Materials," but when it comes to "Evaluating Rank," it becomes uncanny. Unless one has a bright mind, one cannot follow

\footnotetext{
85 “Xuanyang: Ri yue yun xia,” Xiupu, 4b; in Congshu jicheng xubian, vol. 79, 797.
} 
it. When I read it aloud repeatedly, I would suddenly feel my mind opening up. So I copied it out once by hand from beginning to end to express my admiration. Only the summer heat was sweltering, the rain humid, and the clouds like steam. My feeble script was crooked like mosquito legs, and I felt ashamed at my weak wrist. But I was pursuing what my heart delights in and almost forgot the unbearable heat. As my brush danced in motion, I completed it within ten days. So I record a few words at the end of the book. On a summer day in the year Wuzi (1828 or 1888), postscript written in Huanhuage by Jin Xiang of Jiahe. ${ }^{86}$

Ding Pei's text put into words what Jin Xiang was not able to articulate but strongly felt about various aspects of embroidery. Reading the Xiupu made such a strong impact on her that she decided to hand-copy it out of admiration. In this enthusiastic response of one reader, we can locate possibilities of women as writing subjects, readers, and embroiderers in their everyday life. In small but concrete ways, one woman's text played a meaningful and productive role in the lives of women of different age groups and time periods who had come into contact with it.

\section{Technologizing Embroidery: Engendering a Modern Craft ${ }^{87}$}

\footnotetext{
${ }^{86}$ I have not been able to identify Jin Xiang. Without a reign period designation, the year Wuzi could be 1828 or 1888 . All three editions of Xiupu (see n. 9) include this colophon, which suggests that the extant version today is the one copied by Jin Xiang.

${ }^{87}$ In revising this section, I am particularly indebted to the insightful comments of one of the anonymous readers.
} 
The life and work of the most famous embroiderer Shen Shou were inextricably caught up in the radical political, social, and economic changes of the late Qing and early Republican period. Here, I intend to focus on the extraordinary circumstances of Shen Shou's life that are bound up with the complicated transition into modernity. I will comment on the ironic, "hybrid" production of Xuehuan xiupu — the most comprehensive manual on Chinese embroidery which bears her style name Xuehuan, and reflect on its complex relation to questions of women's work, literacy, and voice in the narratives of Chinese modernity. While it will be beyond the scope of this study to examine in depth the changing values of work and the emergence of women as economic producers in a commercialized, mechanized framework, through the prism of Shen Shou, I hope to show the shifting meaning of the gender-specific field of embroidery in relation to new social formations beginning in the last decade of the Qing dynasty. As I will show, the very realm of the everyday in connection to the practice of embroidery was altered from the local, homosocial space that women in the late imperial period were able to construct for themselves by taking embroidery as one of their cultural tools for self-assertion and agency, to a mode of economic production promoted by male reformers for women's self-support, and by extension, China’s self-sufficiency, in a modernizing context.

Shen Shou and certain aspects of her life have become more popularly known in China due to the recent documentary series Bainian hunlian (One Hundred Years of Marriage and Love) produced by SunTV, ${ }^{88}$ the first episode of which includes a segment on her relationship

${ }^{88}$ I am grateful to my research assistant Lin Fan for calling my attention to this documentary. The series looks at changing meanings and practices of love and marriage in the twentieth century through the lives of a number of “celebrities.” Shen Shou and Zhang Jian's relationship 
with her patron and benefactor Zhang Jian in the last decade of her life. Zhang was an important advocate of political, social, and educational reform and a pioneer of industry and commerce in the late Qing and early Republican period. He was the motivating force behind the production of the embroidery manual and author of its preface. His preface, discussed below, provides a fascinating account of how this functional treatise — bridging old technology and new methodson the craft of embroidery came into being.

Shen Shou was born Shen Yunzhi in Wuxian (present-day Suzhou), an important center of imperial textile production and embroidery (figure 4). Zhu Qiqian (1872-1964), the late Qing and early Republican official, connoisseur and collector of silk embroidery, and a colleague of Zhang Jian, included a brief account of Shen Shou's life in his work, Nügong zhuan zhenglüe (Brief Biographies of Women Needleworkers), published in 1928 in the well-known series on Chinese art edited by the painter Huang Binhong (1865-1955), the Meishu congshu. ${ }^{89}$ As he acknowledged, Zhu had extracted his information from the tomb inscription written by Zhang Jian immediately after Shen Shou's death. ${ }^{90}$ In the tomb inscription, Zhang briefly introduces

is given a romantic reading in the first episode, which also features Liang Qichao and Cai Yuanpei's marriages. The Chinese script for the series is available at http://chinasuntv.com. ${ }^{89}$ In Zhonghua meishu congshu (reprint of Meishu congshu; Beijing: Beijing guji chubanshe, 1998), vol. 18, 4.5.313-315.

${ }^{90}$ See the text of the tomb inscription, entitled "Meishujia Wuxian Shen nüshi lingbiao," in Zhang Jian quanji (The Complete Works of Zhang Jian), 7 vols. (Nanjing: Jiangsu guji chubanshe, 1994), vol. 5, 435-36. 
Shen Shou's modest but respectable family background before focusing on the formation of the young embroiderer from girlhood to her betrothal in adolescence: ${ }^{91}$

At six, she learned needlework and threaded needles for her elder sister. At seven, she learned to embroider. She was concentrated and kept her feelings to herself. When she finished [embroidering] a parrot, she clearly revealed her refinement. At ten or eleven, she endeavored to learn words and was fond of songs and poems. Whenever she finished a piece of embroidery, it would cause a stir among the other girls. By thirteen or fourteen, her reputation had spread. She often worked hard with her sister past midnight, and sold the outstanding pieces for profit. In that way she increased the family's means of livelihood. At fifteen she was betrothed to Yu Zhaoxiong (Yu Jue), a native of Shanyin (present-day Shaoxing). ${ }^{92}$

Using the conventional year-by-year schema in biographical writing, Zhang’s account shows Shen Shou's early life to have followed the familiar pattern of the life cycle for girls growing up

${ }^{91}$ Zhu's account leaves out information regarding her family. In outlining Shen Shou's life, I also draw on Zhang Jian's preface to the Xuehuan xiupu, in Congshu jicheng xubian, vol. 79, 805-806; and the section related to Shen Shou in Zhang Kaiyuan's biography of Zhang Jian, Zhang Jian zhuan (Beijing: Zhonghua gongshang lianhe chubanshe, 2000), 339-48. See also the entry on Shen Shou, in Yu Jianhua, Zhongguo meishujia renmin cidian (Shanghai: Shanghai renmin meishu chubanshe, 1996), 438.

92 I have converted the Chinese way of reckoning age to actual age. Zhang Jian, Zhang Jian quanjuan, Vol. 7, 435; see also the slightly revised version in Zhu Qiqian, Nügong zhuan zhenglüe, in Zhonghua meishu congshu, vol. 18, 4.5.313-314. 
in families with moderate or limited means in the Qing. While she appears to have shown some interest in "songs and poems," she excelled in embroidery and helped to support her family from a very young age. Noteworthy are the sisters' joint efforts at embroidery, recalling the female bonding and culture that developed around this feminine task, which women had written about in their poetry. The biography also highlights Shen Shou's early talent in embroidery in her local, social context among other adolescent girls.

Her betrothal to Yu Jue would have been considered a good match, particularly when he later passed the provincial level examination and obtained the juren degree. After she married Yu at twenty, she continued working on embroidery. It was at this juncture that her practice of embroidery departed from the homosocial world that literate women of earlier generations were able to create through this gender-specific work. Embroidery's economic and commercial value, as well as its status as "art,” began to overtake its affective value in Shen Shou's world. Yu Jue, being adept at painting and calligraphy, helped her draft and design her work, which they then sold. In 1901, Yu Jue took the initiative to offer Shen Shou's embroidery as tribute to the Empress Dowager Cixi upon her return from her "imperial tour" to the west of the capital. ${ }^{93}$ Cixi was apparently so taken with them that she bestowed on Shen Shou and Yu Jue a piece of her own calligraphy with the characters "shou" (longevity) and "fu" (good fortune). Henceforth, Shen Yunzhi changed her name to Shen Shou. This event altered the course of Shen Shou's life from being merely a successful local embroiderer in the Suzhou area to a court favorite, and

${ }^{93}$ Zhang Jian quanjuan, Vol. 5, 436. In Zhu Qiqian's account, it was on the occasion of Cixi's birthday that they presented eight hanging scrolls to her. There are discrepancies in the year (1901, 1903, and 1904) and the number of embroidered paintings presented (two or eight) between the various sources. 
exposed her and her work to the imperial capital and beyond. She was invited to Beijing to take up the post of Chief Instructor of the Section of Embroidery Workers in the Ministry of Agriculture, Crafts, and Commerce. In this capacity she entered the international stage and her fame spread beyond the confines of the empire in the last years of the Qing: in 1905 she traveled with her husband to Japan and learned about the "artistic” embroidery practiced there; in 1909, she exhibited her embroidered portrait of the Italian empress at China’s first world fair-the Nanjing South Seas Exhibition; and in 1911, this portrait won the top award in the international art competition held in Turin, Italy, and the Qing government presented it as a gift to the emperor of Italy (figure 5). ${ }^{94}$ Her most famous work, the embroidered portrait of Jesus, won the first prize at the Panama-Pacific International Exposition (Banama Taipingyang Wanguo bolanhui) in 1915 (figure 6). ${ }^{95}$

${ }^{94}$ Zhang Kaiyuan, Zhang Jian zhuan, 339-40, n. 2.

95 See Yu Jianhua, Zhongguo meishujia renmin cidian, 438; and Zhu Qiqian, Sixiu biji (Records of Silk Embroidery), in Zhonghua meishu congshu, vol. 16, 4.2.383. The latter records the titles of twelve of Shen Shou's “artistic embroideries”-in the form of hanging scrolls and standing screens_-presented to Empress Dowager Cixi, fourteen titles of later works, including information about the portrait of Jesus and the portrait of an American actress named "Beike;" it also appends the text “Origin of the School for Teaching Women’s Handiwork” by Zhang Jian, vol. 16, 4.2.382-386. 
Shen Shou's future patron Zhang Jian was a native of Nantong, Jiangsu. ${ }^{96}$ Until China’s defeat in the Sino-Japanese War in 1895, Zhang's career path through the examination system was typical of scholar-officials in the late imperial era. After numerous attempts at each level, Zhang finally obtained the highest degree (jinshi) at the age of forty-one in 1894, the year in which the disastrous war with Japan broke out. When the Qing government signed the humiliating Treaty of Shimonoseki, which required China to pay a heavy indemnity and give up sovereignty over Taiwan, Zhang Jian became wholly disillusioned with his career as an official in an ineffectual government. He left the bureaucracy to seek more effective means to strengthen his country, one of which was to introduce modernized industrial and commercial ventures in his native Nantong, such as establishing and operating the Dasheng Cotton Mill to great profit. The huge success of Zhang's local projects brought him recognition by and respect from his contemporaries and the imperial government. Also an ardent advocate of educational reform, Zhang established the first normal school in China in Nantong in 1902, which he expanded in 1909 to include training for women teachers. ${ }^{97}$

${ }^{96}$ For a succinct account of Zhang Jian’s life and career, see Howard L. Boorman, ed, Biographical Dictionary of Republican China (New York: Columbia University Press, 1967-79), 1.35-38.

${ }^{97}$ In 1905, Zhang also founded the first museum in China in Nantong. Embroidered works were among art objects in the collection. See Wang Hongjun, ed., Zhongguo bowuguanxue jichu (The Basis of Chinese Museology) (Shanghai: Shanghai guji chubanshe, 1990), 79-83. On Zhang's writings on education, see Marianne Bastid, Educational Reform in Early Twentieth-Century China, trans. Paul J. Bailey (Ann Arbor: Center for Chinese Studies, University of Michigan, 1988). 
In 1909, when the Qing government organized the Nanjing South Seas Exhibition (Nanyang quanyehui), Zhang Jian was asked to be in charge of evaluating the products solicited for participation from the various provinces in the empire. ${ }^{98}$ This grandiose event was imperial China’s first attempt to join the great European powers in hosting an international exposition, which showcased to the world both China's modernization and her cultural heritage. As noted by Michael R. Godley, “[n]ot only were there displays of modern armaments and machinery, but a fully equipped emergency hospital and three new electric light plants. . . . The arts and products of traditional China were all well represented, but they were accompanied by nationalist slogans and enclosed in the modern structures which made them seem antique."99 In his preface to the Xuehuan xiupu, Zhang recorded that the Ministry of Commerce put Shen Shou in charge of assessing the authenticity of embroidered works. She came from Beijing in this function and exhibited her embroidered portrait of the empress of Italy. Zhang Jian, twenty-three years her senior, was extremely impressed not only by this tour-de-force, but also by Shen Shou's remarkable ability to authenticate a screen embroidered by women of the renowned Gu family of the late Ming by identifying the method of the stitching. He immediately sent a woman student from Nantong to study with Shen Shou in Beijing. ${ }^{100}$

After the 1911 Revolution brought an end to Qing rule, Shen Shou and her husband moved to Tianjin and set up an institute for teaching women's crafts and taught embroidery as a

\footnotetext{
${ }^{98}$ On the aims, organization, and outcome of this first international exhibition held in China, see Michael R. Godley, “China’s World’s Fair of 1910: Lessons from a Forgotten Event,” Modern
} Asian Studies 12.3 (1978): 503-22.

${ }^{99}$ Michael R. Godley, “China’s World’s Fair of 1910,” 504.

100 “Xu,” 1b-2a, Xuehuan xiupu, in Congshu jicheng xubian, vol. 79, 805. 
means to support themselves. Fearing that her art and skill would be lost, Zhang Jian set up an annex to the women's normal school to provide instruction in embroidery and invited Shen Shou to relocate to Nantong to be the director. He said only then did he "get to know her." ${ }^{\text {,101 }}$ Shen Shou was almost forty at the time and in poor health. Zhang wrote that he felt even more the urgency of transmitting her craft. When Shen Shou was well enough, he asked her about her "method" and recorded her reply:

I did not receive special instruction in needlework. I just learned it when I was small and practiced it when I grew up. It was the old way. I realized that embroidering is to produce the image of things. When things have truth in themselves, we should let the truth come out. I saw that European lithography and oil paintings are based on capturing the reflection (sheying). ${ }^{102}$ Reflection arises from light, and light has yin and yang. When I differentiated yin and yang, I thought deeply and infused my old methods with new ideas. Gradually I progressed. Then when I visited Japan, I benefited a great deal from being able to observe their "artistic embroidery.” As time went by, I came to feel that whenever any of the myriad forms and expressions in the world enters into my vision, they can all be entered into my needle. In other words, they can all be entered into my embroidery. ${ }^{103}$

The master embroiderer's discourse on her art was what inspired Zhang Jian to initiate their cooperative oral-to-written project that resulted in the Xuehuan xiupu, a unique "ethnographic" record of the art and technology of embroidery that bears Shen Shou's style name Xuehuan. He

101 “Хu,” 2a, Xuehuan xiupu, in Congshu jicheng xubian, vol. 79, 805.

102 Sheying is the term that was used for photography.

103 “Xu,” 2a-2b, Xuehuan xiupu, in Congshu jicheng xubian, vol. 79, 805. 
asked her to "consider meticulously from beginning to end every fact—every stitch and every method—concerning the practice of embroidery and to speak about them in detail.” His motivation and participation in this process are revealed as he continues in the preface:

I categorized and recorded them (the detailed information) for her. Sometimes we would do one or two entries in a day, other times we would take two or three days to complete one entry. I arrange them in order so as to present point by point what can be transmitted in her method and set up topics in order to include the ideas that cannot be transmitted. In language I do not seek for the profound but aim for what can easily be understood by young women; in technique I dare not involve the far-fetched and implausible but to provide proof for those who learn to embroider. We completed this manual after several months. I repeatedly revised the draft upon examining and asking her about it. There is not one written word that did not come from me, but in truth there is not one spoken word that did not come from Shou. ${ }^{104}$

The Xuehuan xiupu was completed and published in early 1919, on the eve of the May Fourth Movement and two years before Shen Shou died. In his abridged biography of Shen Shou, Zhu Qiqian lists the eight section headings and refers to the book as the comprehensive guide to embroidery: "Bringing together Chinese and foreign, it contains true knowledge gained from long practice and so can serve as a guiding principle to later generations. Moreover, it is a pioneer of specialized books on Chinese arts and crafts. Ding Pei's manual decidedly cannot be spoken of in the same breath." ${ }^{105}$ As avant-garde Chinese writers were in the midst of

\footnotetext{
104 “Xu,” 2b, Xuehuan xiupu, in Congshu jicheng xubian, vol. 79, 805. Emphasis mine.

105 Zhu Qiqian, Nügong zhuan zhenglue, in Zhonghua Meishu congshu, vol. 18, 4.5.315.

Emphasis mine. A one-line biographical entry on Ding Pei is also included in Zhu's work, which
} 
experimenting with the vernacular language as the vehicle of creativity and communication, it is somewhat ironic that this detailed treatise on embroidery—orally narrated by Shen Shou in the vernacular—was transcribed into the literary language that was Zhang Jian's learned medium of communication, even when Zhang had stated in his preface, "In language I do not seek for the profound but aim for what can easily be understood by young women.” And yet, this classical language was not the common language of young women workers, to whom this traditional feminine craft was being promoted as a means of livelihood in a modernizing world by a male reformer with the best of intentions. Zhang's language also largely hides Shen Shou's voice and individuality, and it aestheticizes the text by making it "literary."

The eight categories into which Zhang Jian organized the work are: 1. Xiubei (Preparation for Embroidery), which discusses the types and specifications of embroidery stands, frames, scissors, and needles. Two illustrations for stands are provided. 2 Xiuyin (Beginning Embroidery), which instructs the embroiderer in various ways of working with thread: cutting, connecting, smoothing, moistening, etc. 3. Zhenfa (Stitches), which has entries on thirteen types of ordinary stitches and eighteen types of special stitches, including instructions on how they are executed, and what subjects they are suited for. 4. Xiuyao (The Fundamentals of Embroidery) is the longest and most detailed section. The matters discussed concern layout or design, the use of colors (which includes a complex chart on the subdivisions of various colors), chiaroscuro, realism, subtle effects, and the philosophy of meticulousness. Together, sections 3 and 4 provide the most detailed technical instructions, making the Xuehuan xiupu truly a user's manual, from

identifies her name, native place, where she married to, the family name of her husband, and the fact that she was skilled in embroidery and had written the Xiupu. It then quotes Ding Pei's preface in full. 
which one can learn to apply the actual techniques. In contrast to the detailed length of the first four sections, the last four are quite terse: 5. Xiupin (The Character of the Embroiderer) is a short passage on the proper way to sit and general deportment. ${ }^{106}$ 6. Xiude (The Virtue of Embroidering) discourses briefly on economy or frugality with regard to using the materials. 7. Xiujie (The Time Periods for Embroidery) is one of a few passages in which Shen Shou speaks in the first person about how she had ruined her health by sitting and embroidering day and night for long periods of time. She recommends sitting for two hours at a time; after each period one should get up to move around before resuming. Together with the instruction on how to sit properly in section 5, this section also provides sensible ergonomic advice derived from personal experience, as did Ding Pei in her manual. The final section (8), Xiutong (Making Connections in Embroidery), points out how, because of the artistic similarities between embroidery and painting and calligraphy, one can make progress by learning to see parallels with these arts in terms of degrees of difficulty. As we have seen, this comparability was also emphasized in the Cixiu tu and the Xiupu.

As is to be expected, the manuals by Ding Pei and Shen Shou reflect different conceptions of readership and use. On the one hand, Ding Pei was writing in response to gentry women friends who were familiar with the basic techniques of embroidery. She had in mind potential readers like the young gentry women who wrote about their everyday experience of embroidery. Therefore, she emphasized that embroidery was a cultivated art equal to that of painting and calligraphy, which also required aesthetic discernment on the part of the practitioner. Shen Shou's manual, on the other hand, as intended by Zhang Jian, is aimed at the detailed preservation of her art for the purpose of teaching women who might have little

106 Note the different meaning given to pin (character, rank, deportment) by the three manuals. 
knowledge of the traditional craft of embroidery, but who might be able to master it as a means towards economic self-sufficiency. As my discussion of the language suggested above, although Zhang Jian's project to promote a traditional women's handicraft in a modernizing world is not without contradiction and nostalgia for a self-sufficient China in a period of transition, ${ }^{107}$ the pragmatic orientation of the Xuehuan xiupu is clearly visible. While both manuals contain the directive that beginners should start with embroidering flowers and plants, which must have been a common view, Ding Pei, if we recall, went on to illustrate her point by making an analogy between the first stage of embroidery with the first lessons in literati activities such as studying the classics, painting, calligraphy, and playing the qin. In Shen Shou's manual, this directive is contextualized in actual practice, for it is given under the first type of ordinary stitching — qizhen "even stitching," where she provides a technical description of how one should work the needle and thread to achieve this type of stitching. ${ }^{108}$ Her level of instruction can be extremely concrete and practical. For example, her advice on how to cut the thread goes: "When one has used up a length of thread, one must lie the needle on the surface of the forefinger to cut the thread that is still in the needle hole. This most likely will not damage the hole and the needle can be used for a long time." ${ }^{109}$

Alongside the text of Shen Shou's practical instructions, Zhang Jian frequently provides interlineal annotations that seem inappropriate for the level and stated aim of the text. For the passage quoted above, for example, he provides an annotation for the term shizhi (forefinger) by

${ }^{107}$ In addition to the misfit between the level of language and the level of audience, there is a certain contradiction in Zhang's simultaneous promotion of embroidery as new art and old craft. ${ }^{108}$ In section 3 “Zhenfa,” Xuehuan xiupu 4b, in Congshu jicheng xubian, vol. 79, 808. 109 Xuehuan xiupu 4a, in Congshu jicheng xubian, vol. 79, 808. 
referring to the Zuozhuan: “In the annotation for 'Zigong's shizhi moved' in Zuozhuan, it refers to the second finger." ${ }^{110}$ Many of Zhang's interlineal annotations are in fact references to the dynastic histories and Confucian classics, the scholarship in which he is trained. Was Zhang aware that the terms and language he used might not be immediately apparent to the average reader or embroiderer, since classical references would further obscure the meaning or be irrelevant to such users? Or did he also have in mind another readership—classically educated men like himself? Was he attempting to elevate the text by annotating it with reference to classical texts? The two purposes and two audiences run counter to each other. The mixing of discourses in this manual is perhaps the inevitable but peculiar result of the condition of its production. When the Xuehuan xiupu was produced, Shen Shou had been teaching for seven years at the Institute for the Instruction of Women’s Needlework (Nügong chuanxisuo) that Zhang Jian had founded for her in Nantong. Before her death two years later, the institute had graduated more than one hundred and fifty students and the Shen style of embroidery had been established outside the family model. Zhang Jian’s project, with Shen Shou’s important contribution, achieved some measure of success in its own local and limited way. ${ }^{111}$

110 Xuehuan xiupu 4a, in Congshu jicheng xubian, vol. 79, 808. Zhang Jian begins the preface with a short "scholarly" history of embroidery in China.

${ }^{111}$ For further details on the school’s curriculum, see Zhang Kaiyuan, Zhang Jian zhuan, 342-43. One of the anonymous readers suggests that the "school ... tried to sustain itself by selling students' homework.” It might have done this, but I believe the school was heavily, if not entirely, subsidized by Zhang Jian. See the numerous charitable schools and philanthropic projects he personally financed in Nantong in the last two decades of his life, in Howard L. Boorman, ed., Biographical Dictionary of Republican China, 38. 
As I have noted above, occasionally Shen Shou’s personal “voice” breaks through in this literary rewriting of her knowledge and experience. In terms of her innovative directions in embroidery, her contact with Western oil painting and photography in the Qing court and her travel to Japan probably had the most effect on her thinking and practice. Under the subtopic "Subtle effects" (miaoyong) in Section 5 (Essentials of Embroidery), Zhang Jian transcribed her talk regarding how she had based her famous embroidered portrait of Jesus on a photograph of an oil painting, and how she experimented with different color combinations of the threads in order to be able to reproduce the lighting and realistic effects. She also discussed the new stitches she learned in Japan that were not in the Chinese repertory. ${ }^{112}$ Clearly, as an artist, she set her vision beyond tradition and was eager to try out novel techniques to bring her embroidery to new levels of achievement.

I believe Shen Shou was literate, although the level of her literacy may not have been very high. She embroidered characters and calligraphy. She made references to them in her discussions. But she did not develop into a writer-poet as did many of the literate women we encountered in the first part of this study. We probably cannot now determine whether this absence of writing was due to economic circumstances, social background, personal inclination, or a combination of the above. Zhang Jian mentioned in the tomb inscription that for a time Shen Shou had studied how to compose poetry with him. All her life Shen Shou devoted her energy and time to embroidery. Like many women before her, she transformed her talent and skill into a viable means of livelihood. When giving advice on how long to sit, she revealed her excessive diligence in the past as a cautionary example: "Since the age when I had my hair pinned up (fourteen or fifteen) I worked day and night. Sometimes I would work past midnight and light

${ }^{112}$ Xuehuan xiupu 23a-b, in Congshu jicheng xubian, vol. 79, 818. 
the lamp to replace the candle. After I married, I did not relax but continued. In the time after preparing meals, I felt rushed by day and hurried by night, sitting at it until I became ill."113

Shen Shou's extraordinary talent was co-opted by the Empress Dowager Cixi and the Qing court. She later joined ranks with a social reformer who wanted to draw on China's traditional crafts to enable the economic survival of women in the modern era, an effort with limited results. To Zhu Qiqian, who was also writing in literary Chinese in the 1920s and eager to promote the utility of embroidery and its preservation as art, the technological precision and thoroughness solicited by Zhang Jian that characterize the Xuehuan xiupu rendered this manual far superior to Ding Pei’s text. However, although Zhu Qiqian was not a radical reformer, his reading of these texts has been altered by the different social and economic agenda of the time. In hindsight, this altered vision can be seen to rest awkwardly with the continued privileging of certain “old” cultural forms such as the literary language. Zhu Qiqian and Zhang Jian were both modernizers who also did not abandon traditional Confucian values. As Minister of Internal Affairs (Neiwubu) in the early Republic, Zhu played an active role in the urban and cultural projects that transformed the imperial palace into a public space and venue for the exhibition of antiquities. ${ }^{114}$ But in their eagerness to bring embroidery into the domain of modernization, they

${ }^{113}$ Xuehuan xiupu 25b, in Congshu jicheng xubian, vol. 79, 819.

${ }^{114}$ See Wang Cheng-hua, “Imperial Treasures, Art Exhibitions, and National Legacy: The Institute for Exhibiting Antiquities in the 1910s" (paper presented at the workshop "Memory Links: To Self, Culture, and Country in Chinese History,” Indiana University, October 31 November 2, 2003), 10-12; Mingzheng Shi discusses Zhu's involvement with the creation of Beijing’s first public park in “From Imperial Gardens to Public Parks: The Transformation of Urban Space in Early Twentieth-Century Beijing,” Modern China 24.3 (1998): 234-41. 
have unfortunately contributed to the obscuring of the local knowledge and subtle effects of women’s agency in the everyday in an earlier era.

\section{Conclusion}

While embroidering was closely associated with women's moral and aesthetic cultivation in gentry families in the late imperial period, its class basis and status changed rapidly with modernity. As the post-1911 efforts of both Zhang Jian and Shen Shou show, embroidery was turned from an everyday practice among elite women into a modern craft that could have provided a means of livelihood to women workers. This new context, ironically, foregrounds the crucial roles men played in the "business” of embroidery: from Yu Jue’s designs and drawings and his marketing, to Zhang Jian’s embroidery school and his co-writing of Shen Shou's manual. Even in a field that was ostensibly women's specialized skill and knowledge, women remained notably dependent and subordinate in the new commercialized and globalized economy. ${ }^{115}$ With the accompanying changes in ritual and social practices, lifestyles, and fashion, the demand for the various embroidered products also greatly diminished in comparison to their former ubiquity in Chinese life. This social and material transformation greatly reduced the commercial viability

${ }^{115}$ Although dependent on male patrons in her early entry into the educational and journalistic professions in the late Qing, Lü Bicheng stands as an outstanding example of female entrepreneurship and autonomy in the early Republican period. See my study, "Alternative Modernities, Or a Classical Woman of Modern China: The Challenging Trajectory of Lü Bicheng’s (1883-1943) Life and Song Lyrics,” NAN NÜ: Men, Women, and Gender in China 6.1 (2004). 
of this “traditional women’s craft” just at the time when it was given a public, even nationalistic significance. $^{116}$

My narrative in the second part of the study pointed to three significant moments in the practice of embroidery: evidence of the aestheticization of embroidery as an art with the appearance of the Cixiu tu in the late Ming, the internalization of that aesthetic into a facet of elitist feminine identity as evinced in Ding Pei's Xiupu, and the simultaneous transformation of embroidery into a traditional art and technical craft in the modern era in which Shen Shou participated. The first two moments form an almost seamless suture underscored by the pervasive inscription of embroidery in women's poetry. They aestheticized an everyday practice in the self-expressive act of writing. Not only did women see embroidery as one among other types of cultural knowledge and practices within their command such as book learning, calligraphy, painting, and poetry, it was a field in which they saw themselves as the true practitioners and authorities. As a knowledge field so closely connected to daily life in the inner quarters, embroidering was transmitted concretely through practice and direct teaching from mother to daughter, from aunt to niece, from elder to younger sister, from women to women. Much of this practice was localized and taken for granted. It was inseparable from women’s sense of the everyday. In addition to poetic inscription, a significant few also articulated this gender-specific knowledge and expertise by writing manuals. That they did so is an indication of their awareness of a community of women readers and practitioners who shared this specialized field. Through the textual legacy and the embroidered objects left by women, we can recover and

\footnotetext{
116 To maintain a measure of profitability, producers of embroidery began to (and continue to) tap foreign markets and tourist consumption. Foreign missionaries collected embroidery, and pieces were also sent overseas where they can now be found in antique stores and museums.
} 
give due recognition to their knowledge and their perception of the practice of embroidery as alternative social and creative spaces for limited agency and empowerment, much in the same way as the recent rediscovery of the practice of nüshu (Women's Script) in a remote county in Hunan has shown how subcultures could exist and thrive in remarkably marginalized and difficult circumstances. ${ }^{117}$ A complete rupture obtains between the practice of embroidery in late imperial women's culture and that in the modernizing moment. Much of this break, in a fundamental sense, is connected to the radically altered meaning of the everyday for women of varied social classes and their entry into public life, along with the changed value and meaning of embroidery, indeed of women's work and womanhood itself.

\footnotetext{
${ }^{117}$ It has been suggested that the local geometric embroidered patterns had an influence on the creation of the symbols in the nüshi script.
} 


\section{Appendix: Chinese Texts}

The numbers refer to the footnote numbers following the translations of the cited texts. The title of each poem is given inside [] following the text.

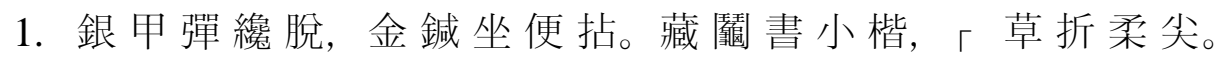

易 覆情 難定，能舒軟不嫌。金梭機畔 織，窄袖 隱 纖 纖。[手]

14. 女則課紡績，男則課詩書。[婦誡]

16. 機中定織百尺練，枉「他人作鍼線。[紡 績 嘆]

17. 軋軋機杼聲, 漠漠空天雪。操作入中宵, 十指皆紴裂。

積絲豈易成，不忍中道「。著此縞素衣，怡然歸同穴。[述懷]

21.十三學刺「，十五學吟詩。[自傷］

27. 今歲今宵盡, 明年明日來。流梭人不覺, 覽鏡影相猜。

徂得團「樂，何妨節序催。新詩成刻燭，縉罷也同裁。[除夕和諸兄韻]

30. 只理香絨不理妝，金針停刺細思量。

而今多厭閒花草, 聊檢 新詩 錦 繡 囊。[刺繡]

33. 香沾繡帙同分線，春暖妝台互迻花。[鄰女因胥無籍淪於塞下聞而有感]

34. 繡罷頻呼「妹看，暖風晴日滿闌干。[春 閨]

35. 憶昔十三餘，倚床初學 繡。[夏初「女學繡有感]

36. 睹繡當窗隨臥起，種花隔夜費商量。[與 $「$ 別後頗無意 $「$ 感舊述懷得七律十六韻]

37. 苓床繡罷慣垂肩，一擲光陰已卅年。[雨夜不寐有懷靜宜樓四妹]

38. 料得書長針線懶，倚樓也念遠離人。[懷幼嫻四妹]

39. 手理紅絨坐綠窗，懷人「覺書偏長。 
回思昔日湘笠下，共 把金針繡鳳凰。[寄懷吳姑母]

40. 繣餘靜坐發「思，煮若添香事事宜。

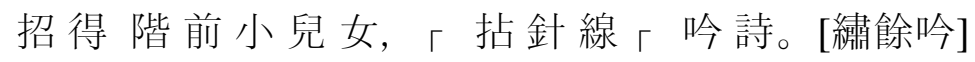

42. 爾我襟期喜共知，笑言頻到漏殘時。

開织會看將完繡，剪燭閒敲未定詩。

金鴨灰深香䇡細，晶篻風定落花遲。

「來又恐輕言別，月底燈前繋夢思。[喜高本表妹至]

43. I. 結 伴深閏十七年，繣餘「學大家篇。

如何天上修文去，不肯人間秘盡傳。

IV. 鍼「功餘筆自隨，手抄名媛百家詩。

茂渏書法傳「格，滿需珠璣欲付誰。[(哭「) 又 $「$ 句十首]

44. 針「與圖書，左右陳閒錯。[春日抒懷]

45. 窗前刺紼嫌時短, 燈下敲詩喜漏長。[冬日雜感]

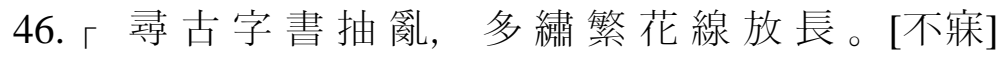

47. 或藻思綺合, 「麗芉眠，炳若縟繡。[文賦]

49. 軋軋九張機, 機上朱絲錯。織成璇璣圖, 文章在 閏閣。[偶作]

50. 山靜偏宜暑, 松風入夢「。危岩飛雨色, 古樹咽蟬聲。

刺繡年來課, 看雲物外情。不知塵市遠, 聊「證無生。[夏日山居]

52. 紼佛長齋已牛生, 人天道隔精誠貫。[馬貞孝女詩]

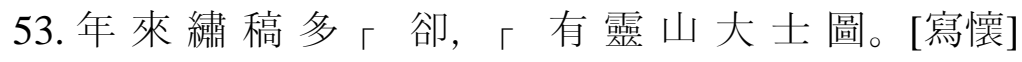


54. 花容玉面見慈心, 寶笺横空隱竹林。

南海有津誰 渡 我, 刺成 童子拜 觀 音。[題自紼善才拜觀音圖]

58. 斯固妝樓之佳事, 抑亦縹素之逸編也。聊寄莞爾, 曲或譏焉。

61. 度鍼欲輕重如書法之錯落, 結線欲疏密如畫家之寫生, 庶非紅女。

62. 名香「花畫「風髹几碧紗如煙蓄薇露拭 雛侍史。

63. 暄風爽日秋夜長春寒花壓欄杆竹影上「風笠燕入「子塗门。

64. 入冬罷刺繡, 閑坐擁爐吟。[冬日即事]

\section{Glossary}

Bainian hunlian 百年婚戀

Ban Zhao 班 昭

Banama Taipingyang Wanguo bolanhui 巴 拿馬太平洋 萬 國博覽 會

baxiu ji 罷 繡集

Beike 倍 克

Bianse 辨色

$b u$ 部

Cai Yuanpei 蔡元 培

$c a i$ 裁

Caipin 才品

Can jing 簣 經 chan 禪

Chen Shulan 陳淑 蘭

Chen Yugang 陳毓「 (Liangqiao 兩橋)

Chenggong 程工

Cixiu tu 刺 繡 圖

\section{Dianzhui 點 綴}

Ding Pei 丁 佩 (Bushan 步 珊)

Dong Xuehui 董雪暉

$F a$ 法

fang 紡

Fu Mengqin 富夢琴

$f u$ 福 
Fujie 婦誡

fuli 富 麗

Fulu 附錄

Gan Lirou 甘立「

gaochao 高超

Gong 供

gong 紅

Gongwei 宮闈

Guige 閨 閣

Guochao guixiu zhengshi ji 國朝閆秀正 始集

Hang Wenru 杭溫如

$\mathrm{Hou}$ 候

Hu Wenkai 胡文楷

Hua suoshi 花頱事

Huaguo caomu 花果草木

Huang Binhong 黃賓虹

Huang Lixiang 黃 儷 祥

Huang Xingzeng 黃省曾

Huang Yunxiang 黃雲 湘

Huating 華亭 $j i$ 機

$j i$ 績

$J i$ 際

jiancai zhi li 剪裁之力

jie 潔

Jiexia 節 俠

Jin Tingqiu 金聽秋

Jin Xiang 金 湘

Jin $\mathrm{Yi}$ 金逸

jing 靜

jinggong 精 工

jinshi 進士

jinxin xiukou 錦心繡口

Jiuyang cao 就養草

jizhu 機 杼

juanxiu ji 倦繡集

Jujia bibei 居家必備

Kong Jiying 孔 繼 英

Kuiyu cao 饋 餘 草

Lanxi 荿溪

leishu 類書 
$\mathrm{Li} \mathrm{He}$ 李賀

Li Qinghui 李「輝

Li shi 李氏

Liang 梁

Liang Qichao 梁「超

Liao Yunjin 㦄雲 錦

Liechao shiji (Runji) 列朝詩集 (閏集)

liyan 例 言

Lü Bicheng 呂碧城

Lu Ji 陸機

lü 綠

Lüchuang nüshi 綠省女史

Lunpin 論品

Ma 馬

Meishujia Wuxian Shen nüshi lingbiao 美

術家吳縣沈女士靈表

miao 妙

miaoyong 妙用

ming 明

Minggan 冥感

Mingyuan shigui 名媛詩歸
Mingyuan shihua 名媛 詩話

Mingyuan shiwei 名媛詩緯

nangeng nüzhi 男耕女織

Nanyang quanyehui 南洋勸業會

Neiwubu 內務部

neng 能

nügong 女 紅

Nü jie 女誡

Nü lunyu 女 論語

Nü xiaojing 女孝經

Nüfan 女範

Nügong chuanxisuo 女工傳習所

Nügong zhuan zhenglüe 女紅 傳徵略

nüshu 女書

Ouxiang nüshi 藕香女史

Peilanxuan xiuyu cao 佩蘭軒繡餘草

Pin 品

$p u$ 譜

Qi 齊

Qi 器

Qian Qianyi 錢 謙 益 


\begin{tabular}{|c|c|}
\hline qiao 巧 & shen 神 \\
\hline Qiebi 妾婢 & Shenxian 神仙 \\
\hline qing \ulcorner & sheying 攝影 \\
\hline Qinglou $\ulcorner$ 樓 & shizhi 食指 \\
\hline qingxiu 「秀 & Songjiang 松江 \\
\hline Qinhuai Yuke 秦淮寓客 & Su Hui 蘇 蕙 \\
\hline qizhen 齊鍼 & Suiyuan nüdizi shixuan 隨園女弟子詩選 \\
\hline Qu You 瞿祐 & Sun Xuying 孫旭 英 \\
\hline Qucai 取材 & Tang Xiangzhi 湯 湘 芷 \\
\hline ren \ulcorner & Tao Xiang 陶湘 \\
\hline Ri yue yun xia 日月雲霞 & $t u$ 圖 \\
\hline Rongyi 容儀 & Wang Duanshu 王 端淑 \\
\hline Sanmao 三 「 & Wang Feiqiong 王 飛瓊 \\
\hline Shanshui renwu 山水人物 & Wang Hui 王 慧 \\
\hline shang 商 & Wang Shilu 王士祿 \\
\hline shanjiao 山 椒 & Wang Wei 王 維 \\
\hline Shao Qiaoniang 邵巧娘 & Weiwang cao 未亡草 \\
\hline Shen Shanbao 沈 善 寶 (Xiangpei 湘 佩) & Wen Huang 文筀 \\
\hline Shen Shou 沈 壽 & Wuxing 吳興 \\
\hline Shen Yixiu 沈宜修 & Wuyunzhu烏雲珠 \\
\hline Shen Yunzhi 沈雲芝 & $x i a$ 霞 \\
\hline
\end{tabular}


xian 閒

xiao ernü 小兒女

xingqing 性 情

Xinyuan tang 心遠 堂

$x i u$ 繡

Xiubei 繡備

Xiude 繡 德

Xiujie 繡節

Xiupin 繡 品

Xiupu 繡譜

Xiutong 繡通

Xiuyao 繡 要

Xiuyin 繡引

Xiuyu cao 繡 餘 草

Xiuyu yingao 繡 餘吟稿

xiuyu 繡 餘

Xiyongxuan congshu 喜咏軒叢書

$\mathrm{Xu}$ Zaipu 許 在 璞

Xu zhuan 序傳

Xuanyang 選樣

Xue Susu 薛素素
Xuehuan xiupu雪宦䋓譜

xuexiu ji 學 纁集

Yan 燕

Yan Liu $\ulcorner\quad\ulcorner$

Yang Weizhen 楊 維 禎

Yaoyan 妖 「

Ye Shaoyuan 葉紹袁

Yifan 儀 範

Yongxuelou shicun 詠雪樓詩存

$\mathrm{Yu}$ 豫

Yu Jue 覺 (Zhaoxiong 兆熊)

$y u$ 餘

Yuan Zhu 袁 杼

Yuan'ou 緣偶

Yun Zhu 惲 珠

yun 雲

Yunjian 雲間

Zalu 雜錄

Zedi 擇地

Zhang Jian 張 謇

Zhang Kaiyuan 章開沅 
Zhang Shuying 張淑英

Zhang Yigu 張義姑

Zhang Yuzhen 張玉 珍

zhen 針

Zhenfa 鍼 法

zhengkai 正楷

Zhenjian 鍼剪

Zhi 質 zhi 織

Zhijin xuanji tu 織錦璇璣 圖

Zhong Xing 鍾 惺

Zhongkui lu 中 饋 錄

Zhou Shulü 周 淑履

Zhu Qiqian 朱 「 欽

Zhuzhuan 著撰

zixu自「

\section{References:}

Bainian hunlian. TV documentary series. http://chinasuntv.com.

Bastid, Marianne. Educational Reform in Early Twentieth-Century China. Trans. Paul J. Bailey. Ann Arbor: Center for Chinese Studies, University of Michigan, 1988.

Boorman, Howard L., ed. Biographical Dictionary of Republican China. New York: Columbia University Press, 1967-79.

Bray, Francesca. Technology and Gender: Fabrics of Power in Late Imperial China. Berkeley: University of California Press, 1997.

Chang, Kang-i Sun. “Ming and Qing Anthologies of Women’s Poetry and their Selection Strategies,” in Ellen Widmer and Kang-i Sun Chang, eds., Writing Women in Late Imperial China. Stanford: Stanford University Press, 1997.

Certeau, Michel de. The Practice of Everyday Life. Berkeley: University of California Press, 1984. 
Ding Pei. Xiupu. In Congshu jicheng xubian (Shanghai: Shanghai shudian, 1994), vol. 79, 795804.

Fong, Grace S. “Alternative Modernities, Or a Classical Woman of Modern China: The Challenging Trajectory of Lü Bicheng’s (1883-1943) Life and Song Lyrics.” NAN NÜ:

Men, Women, and Gender in Early and Imperial China 6.1 (2004). . “Counter-Canon Effects: Anthologizing Women’s Poetry in the Late Ming,” paper presented at the international conference "Poetic Thought and Hermeneutics in Traditional China: A Cross-Cultural Perspective,” Yale University, May 1-4, 2003. . “Imagined and Real Communities: Shen Shanbao’s (1808-1862) Critical Discourse on Women's Poetry,” paper presented at the Annual Meeting of the Association for Asian Studies, Washington D.C., April 4-7, 2002. . “Writing Self and Writing Lives: Shen Shanbao’s (1808-1862) Gendered Auto/Biographical Practices.” NAN NÜ: Men, Women and Gender in Early and Imperial China 2.2 (2000): 259-303.

Gan Lirou. Yongxuelou shicun. 1840 (?) edition. Copy in Harvard-Yenching Library. Godley, Michael R. “China’s World’s Fair of 1910: Lessons from a Forgotten Event.” Modern Asian Studies 12.3 (1978): 503-22.

Grant, Beata. "Who is this 'I'? Who is that 'Other'? The Poetry of an Eighteenth Century Buddhist Laywoman.” Late Imperial China 15.1 (1994): 47-86.

Guo Xueshi and Zhang Zikang, eds. Zhongguo lidai shinü huaji. Tianjin: Tianjin renmin meishu chubanshe, 1998. 
Haraway, Donna. "Situated Knowledges: The Science Question in Feminism and the Privilege of Partial Perspective,” Feminist Studies 14.3 (1988): 575-599.

Hu Wenkai. Lidai funü zhuzuo kao. Shanghai: Shanghai guji chubanshe, 1985.

Knechtges, David, tr. Wen xuan, or Selections of Refined Literature. Princeton: Princeton University Press, 1996.

Ko, Dorothy. Every Step a Lotus: Shoes for Bound Feet. Berkeley: University of California Press; Toronto: The Bata Shoe Museum, 2001. . Teachers of the Inner Chambers: Women and Culture in Seventeenth-Century China. Stanford: Stanford University Press, 1994.

Legge, James, tr. Li ki, in Max Müller ed., Sacred Books of the East (Oxford: Clarendon Press, 1879-85), vol. XXVII-XXVIII.

Liang Baiquan. Wu Yue wenhua: Zhongguo de lingxiu yu Jiangnan shuixiang. Beijing: Shangwu yinshu guan, 1995.

Mann, Susan. Precious Records: Women in China's Long Eighteenth Century. Stanford: Stanford University Press, 1997.

Qinhuai Yuke, ed. Lüchuang nüshi. Late Ming edition. Copy in Harvard-Yenching Library. Robertson, Maureen. “Changing the Subject: Gender and Self-Inscription in Authors’ Prefaces and Shi Poetry,” in Ellen Widmer and Kang-i Sun Chang, eds., Writing Women in Late Imperial China. Stanford: Stanford University Press, 1997.

Ropp, Paul S. et al., eds. Passionate Women: Female Suicide in Late Imperial China. Leiden: Brill, 2001.

Shen Shanbao. Hongxuelou shixuan chuji. 1837 edition. Copies in Beijing, Shanghai, and Nanjing Libraries. 
Shen Shanbao. Mingyuan shihua. Preface dated 1845. Copy in Beijing University Library.

Shen Shou and Zhang Jian. Xuehuan xiupu. In Congshu jicheng xubian (Shanghai: Shanghai shudian, 1994), vol. 79, 805-819.

Shi, Mingzheng. "From Imperial Gardens to Public Parks: The Transformation of Urban Space in Early Twentieth-Century Beijing.” Modern China 24.3 (1998): 219-54.

Swann, Nancy Lee. Pan Chao: Foremost Woman Scholar of China. Rpt.; Ann Arbor: Center for Chinese Studies, University of Michigan, 2001.

Wang Cheng-hua. "Imperial Treasures, Art Exhibitions, and National Legacy: The Institute for Exhibiting Antiquities in the 1910s,” paper presented at the workshop “Memory Links: To Self, Culture, and Country in Chinese History,” Indiana University, October 31 November 2, 2003.

Wang Hongjun, ed. Zhongguo bowuguanxue jichu. Shanghai: Shanghai guji chubanshe, 1990.

Weidner, Marsha et al., eds. Views from Jade Terrace: Chinese Women Artists 1300-1912. Indianapolis and New York: Indianapolis Museum of Art and Rizzoli, 1988.

Widmer, Ellen and Kang-i Sun Chang, eds. Writing Women in Late Imperial China. Stanford: Stanford University Press, 1997.

Xiao Tong, ed. Liuchen Wen xuan huizhu shujie. Taipei: Zhengda yinshu guan, 1974.

Yan Ming and Fan Qi. Zhongguo nüxing wenxue de chuantong. Taipei: Zhonghua jijin guanli weiyuan hui, 1999.

Ye Shaoyuan, comp. Wumengtang ji. Beijing: Zhonghua shuju, 1998.

Yu Jianhua. Zhongguo meishujia renmin cidian. Shanghai: Shanghai renmin meishu chubanshe, 1996. 
Yuan Mei, ed. Suiyuan nüdizi shixuan, in Yuan Mei quanji (Complete Works of Yuan Mei), ed. Wang Yingzhi (Nanjing: Jiangsu guji chubanshe, 1993), vol. 7. , ed. Yuanjia sanmei hegao, in Yuan Mei quanji, vol. 7.

Yun Zhu and Wanyan Miaolianbao, eds. Guochao guixiu zhengshi ji, xuji 1831, 1836 edition. Zhang Jian. Zhang Jian quanji. 7 vols. Nanjing: Jiangsu guji chubanshe, 1994.

Zhang Kaiyuan. Zhang Jian zhuan. Beijing: Zhonghua gongshang lianhe chubanshe, 2000.

Zhang Shuying. Cixiu tu, in Qinhuai Yuke, ed. Lüchuang nüshi. Late Ming edition. Copy in Harvard-Yenching Library.

Zhongguo congshu guanglu.Wuhan: Hubei remin chubanshe, 1999.

Zhongguo congshu zonglu. Rpt., Shanghai: Shanghai guji chubanshe, 1986.

Zhu Qiqian. Nügong zhuan zhenglüe. In Huang Binhong and Deng Shi, eds., Zhonghua meishu congshu. Reprint of Meishu congshu; Beijing: Beijing guji chubanshe, 1998, vol. 18. . Sixiu biji. In Huang Binhong and Deng Shi, eds., Zhonghua meishu congshu. Reprint of Meishu congshu; Beijing: Beijing guji chubanshe, 1998, vol. 16.

Zurndorfer, Harriet. "Women in the Epistemological Strategy of Chinese Encyclopedia: Preliminary Observations from Some Sung, Ming, and Ch’ing Works,” in Harriet Zurndorfer, ed., Chinese Women in the Imperial Past: New Perspectives. Leiden: Brill, 1999. 